\title{
Immunomodulatory Effects of Probiotics in the Intestinal Tract
}

\author{
V. Delcenserie ${ }^{1}$, D. Martel ${ }^{1}$, M. Lamoureux ${ }^{2}$, J. Amiot ${ }^{2}$, Y. Boutin ${ }^{1,3}$ and D. Roy ${ }^{1}$
}

1. Institut des Nutraceutiques et des Aliments Fonctionnels (INAF), Université Laval, 2440, Boul. Hochelaga, Québec, G1K 7P4, Canada

2. Département de sciences des aliments et de nutrition, Pavillon Paul-comtois, Université Laval, Québec, G1K 7P4, Canada

3. TransBIOtech, Cégep de Lévis-Lauzon, $201 \mathrm{Mgr}$ Bourget, Lévis, G6V 6Z9, Canada

\section{Abstract}

The intestinal microbiota is the largest source of microbial stimulation that exerts both harmful and beneficial effects on human health. The interaction between probiotic and enterocytes is the initiating event in immunomodulation and merits particular attention. The effects of probiotic is strain dependent and for each new probiotic strain, profiles of cytokines secreted by lymphocytes, enterocytes or dendritic cells that come in contact with the strain should be systematically established. To evaluate the effects of probiotics on the immune system, models that mimic the mucosa, and thus the physiological reality, should be preferred whenever it is possible. Then, the in vitro observed effects should be backed up by properly conducted randomized double bind clinical studies. More detailed studies are needed to determine the precise action mode of probiotics on both mucosal and systemic immunity.

\section{Introduction}

The immune system of mammals includes a complex array of cells and molecules, which interact to provide protection from challenge by pathogenic microbes (bacteria, viruses, parasites). Antigens, substances that induce an immune response, are often components of invading microbes. Various organs participate in this immune response. For example, the central lymphoid organs (bone marrow, thymus) contribute to the ontogenesis of the different immune cells, while the peripheral lymphoid organs (spleen, lymph nodes, mucosal lymphoid tissue) orchestrate the immune response. As most antigens penetrate the body through the mucosa, the mucosal immune system of the host plays a key role in the defense response to pathogens.

The intestinal microbiota is the largest source of microbial stimulation that exerts both harmful and beneficial effects on human health. It therefore acts as a primary agent as it participates in the development of the postnatal immune system as well as oral tolerance and immunity. It is possible that the microbiota acquired during and immediately after birth is necessary for the newborn's systemic and mucosal immunity, and it may also be responsible for controlling inflammatory responses in allergic and inflammatory bowel diseases. If so, probiotics might impede these inflammatory processes by stabilizing the intestinal microbial environment and intestinal permeability barrier by fostering the degradation of enteric antigens and altering their immunogenicity. Immunostimulation and immunomodulation are the leading proposed explanations for the action mechanisms of probiotics against bacterial pathogens.

A lot of different immunologic studies have been performed in the probiotic field using different strains and different models. The aim of this review was to make the point about the immunological potential of probiotic and to highlight what is already acquired and what is the direction to take to better define an immunologic profile of a probiotic strain.

An excellent review (Cummings et al., 2004) gave very good explanations about the normal function of the gut and the immune system in healthy person with a detailed description of the systemic and mucosal immunity. Our review is divided in two parts. The first, referring to the work of Cummings et al. (2004), briefly described the main actors and answers of the innate and adaptive immune system (1) and the mucosal immune system (2). The second part is focused on the interactions between probiotics and intestinal epithelium and their impact in innate immunity (3), adaptive immunity (4) and more particularly on the Th1/Th2 balance (5). The in vitro tests showing the cytokine profile of probiotic strains are described (6) and clinical studies evaluating the effects of probiotics in the treatment of several chronic inflammatory diseases and allergies are reported (7).

\section{Main actors and main immune answers Innate immune system}

Cells of the innate immune system act as the first line of defence against pathogens but are not overly specific in their ability to recognize their target. A key characteristic of innate immunity is the speed of response. Cells participating in innate immunity react rapidly to challenge by infectious agents, allowing for early protection of the host. The ensuing inflammatory reaction initiates a cascade of events in an attempt to eliminate the invading agent. Key players in the innate immune response include the phagocytic cells like neutrophils, monocytes and macrophages. Macrophages are able to produce cytokines recruiting other inflammatory cells such as neutrophils. Phagocytic cells are attracted to the infection site by chemotaxis. Natural Killer (NK) cells also participate in the innate immune response. NK cells rapidly react to the presence of virusinfected cells in the early stages of infection by killing the 


\section{Lactobacillus Molecular Biology: From Genomics to Probiotics | Book}

Publisher: Caister Academic Press

Editors: Asa Ljungh and Torkel Wadström Lund University, Faculty of Medicine, Sweden

Publication date: January 2009 Available now!

ISBN: 978-1-904455-41-7

Price: GB $£ 150$ or US $\$ 310$ (hardback).

Pages: $x+206$

Lactobacillus is a genus of Gram-positive facultative anaerobic or microaerophilic bacteria. In humans they are symbiotic and are found in the gut flora. Lactobacillus species are used for the production of yogurt, cheese, sauerkraut, pickles, beer, wine, cider, kimchi, chocolate and other fermented foods, as well as animal feeds such as silage. In recent years much interest has been shown in the use of lactobacilli as probiotic organisms and their potential for disease prevention in humans and animals.

This major new work focuses on recent research on the molecular biology and genomics of Lactobacillus. Written by an international team of scientists the volume is an essential reference for all medical researchers, dairy technologists, microbiologists and biotechnologists in the academic and industrial sectors. Topics covered include phylogenetics, taxonomy, comparative genomics, functional genomics, the intestinal microflora, surface proteins, stress responses, interaction with the immune system, probiotics, anti-cancer potential, and much more. Essential reading for all scientists involved with lactic acid bacteria or probiotic research and a recommended book for all microbiology laboratories.

Reviews:

"... an interesting blend of fundamental and applied topics relevant to the use of these important organisms in research and industry. Fundamental aspects covered in the book are taxonomy, metabolism, stress response, genomics, and surface proteins of lactobacilli. Also included are chapters on applications of Lactobacillus strains and their potential as probiotics in the treatment of diseases such as cancer or urinary tract infections." from Biotechnol. J. (2009)

"... contributions from respected international scientists, many of which are leaders in their respective fields, this book constitutes an authoritative resource about both fundamental research and applications of lactobacilli.... essential and up to date information for anyone interested in the biology of lactobacilli. The book will clearly be of interest to microbiologists, nutritionists, food scientists, and medical practitioners alike, and it is a valuable contribution to the probiotic literature." from Biotechnol. J. (2009)

"Lactobacillus Molecular Biology. From Genomics to Proteomics is an essential reference for medical researchers, microbiologists and biotechnologists, especially, dairy technologists." from Mercedes Berlanga, University of Barcelona writing in Int. Microbiol. (2008) 11: $294-295$.

"the chapters are edited competently and constitute outstanding independent reviews ... very informative and provides a comprehensive overview of the genus Lactobacillus" from Knut Heller, Kiel writing in Biospektrum (2009) 15: 348.

"intended for medical professionals, but the conclusions are exciting enough to convince anyone to eat more yogurt." from SciTech Book News June 2009 p. 66 "... a useful guide to how microbiology is developing ... a wide range of important topics ... production is beautiful, with clear diagrams, a nice typeface and two text columns per $17 \times 25 \mathrm{~cm}$ page ... a most valuable text" from Microbiology Today 2009 
infected target cell. They are also believed to play a role in immunological surveillance, killing certain types of tumour cells. Dendritic cells (DCs), along with macrophages and monocytes, provide an interface between the innate and adaptive immune systems as they act as professional "antigen-presenting cells" (APCs). This "bridging" role is crucial in initiating the adaptive immune response, as $T$ cells do not respond to free-antigen but only to antigen that is presented by APCs. Cells of the innate immune system also influence the adaptive immune response through the production of "cytokines": proteins that carry out communication between cells, and are essential in regulating outcomes of an immune response at both the innate and adaptive levels.

Distinction between self and non-self has to be realised by innate immune cells. This distinction is based on the emission of particular signs by pathogens. These signs are common to pathogens but are different of ours. Among them, lipopolysaccarhides of bacteria walls are powerful inductor of immune response. Bacteria flagella or viral nucleic acid are other inductors. Our immune system is able to detect those signs using particular receptors. The innate immunity possesses a family of specialised receptors called Toll-like receptors (TLRs), the "prototypes" of membranous PRR (Patterns Recognition Receptors). These receptors are present in the surface of immune cells and are able to recognize PAMPs (Pathogen-Associated Molecular patterns). For example, TLRs expressed by DCs allows recognition of microbial products which lead to DCs maturation.

\section{Adaptive immune system}

Lymphocytes ( $B$ and $T$ ) are the essential players in the adaptive immune response. The adaptive immune response takes longer to develop than the innate immune response. Specificity and memory are the distinguishing characteristics of the adaptive immune response. The adaptive immune system can provide a more effective protection against pathogens through their ability to recognize and remember an impressive number of antigens. Memory $B$ and $T$ cells provide the host the ability to mount much more effective immune responses against secondary infections. Lymphocytes have specific antigen receptors (BCR for B cells and TCR for T cells) created by genetic rearrangements of variable areas during lymphocyte ontogeny. Thus, each naive lymphocyte has an antigen receptor with a unique specificity. They build a repertoire of polyclonal lymphocytes able to respond to a multitude of antigens.

B cells contribute to the immune response by secreting antibodies (humoral immunity), whereas $\mathrm{T}$ cells act primarily in cell-mediated immunity. T cells can be subdivided into $T$ helper cells (CD4+, also called Th) and $T$ cytotoxic cells $(C D 8+)$. B cells recognize their antigens via their BCR.

$\mathrm{T}$ cells cannot recognize the antigen without some assistance. The antigenic determinant must be presented by an appropriate major histocompatibility complex (MHC) molecule. Thus, they recognize their antigens through their TCR in the form of an $\mathrm{MHC}$ / peptide complex. CD8+ T cells "see" their antigens in the form of a peptide/MHC class I complex, whereas CD4+
$\mathrm{T}$ cells recognize their antigens as a peptide/MHC class II complex. MHC class I molecules are expressed at the surface of all nucleated cells, whereas MHC class II molecules are expressed only by professional APCs. Dendritic cells (DCs) are the major APCs, and they play a critical role in the initiation of the adaptive immune response. Macrophages and $B$ lymphocytes can also act as professional APCs.

It is important to note that the cells of the innate immune system are critical to the initiation of the adaptive immune response. Thus, APC activation is the first step in the induction of adaptive immunity. DCs generally absorb antigens from the environment, and once they are activated (mostly by microbial compounds), they mature and migrate to the adjacent lymphoid tissue. To be activated, T cells must not only recognize their specific antigen in the form of a peptide/MHC complex, they also need a costimulation signal that is provided by the activated APCs.

Once activated, naive $\mathrm{T}$ lymphocytes proliferate and differentiate into effector cells. CD8+ T cells become cytotoxic (CTL), at which point they can target infected cells. CD4+ T helper (Th) cells control the immune response by activating and regulating other cells such as macrophages and $B$ cells.

\section{$C D 4+T$ cell differentiation}

Helper T cells are mainly found in two distinct cell types, Th1 and Th2, distinguished by the cytokines they produce and respond to and the immune responses they are involved in. Th1 cells produce pro-inflammatory cytokines like IFN $\gamma$, TNF $\alpha$ and IL-2, while Th2 cells produce the cytokines IL-4, IL-5, IL-6 and IL-13. The cytokines produced by Th1 cells stimulate the phagocytosis and destruction of microbial pathogens while Th2 cytokines such as IL-4 generally stimulate the production of antibodies directed toward large extracellular parasites. IL-5 stimulates eosinophil responses, also part of the immune response toward large extracellular parasites. On the negative side, Th1 pathway seems to be involved in organ-specific autoimmune diseases such as arthritis and multiple sclerosis when it is overreactive while Th2 pathway is seen as underlying allergy.

The differentiation of naive T cell into either Th1 or Th2 cells is generally dependant of environmental conditions (DCs, cytokines in the milieu, nature and dose of antigen, etc.). The differentiation proceeds within a few days of direct contact of naive T cells with APCs. The process by which commitment develops is called polarization. The naive $T$ cells may pass through a transient state (Th0) on their way to becoming activated cells (Figure 1). Polarization of the Th cells could be indicative of a more profound polarization of the immune system as a whole. In fact, there is good evidence that this polarization already begins with those cells having the primary contact with antigens, including DCs, macrophages and other APCs.

It now seems that Th1 differentiation is reliant on IFN- $\gamma$ and IL-12 whereas Th2 development relies on IL4. The presence of IL-12 induces a STAT-1-dependent signalling cascade that up-regulates expression of the T- 
bet transcription factor, a master regulator that coordinates expression towards Th1 differentiation. Tbet induces IFN- $\gamma$ and IL-12R $\beta$ chain expression, which enables STAT-4-mediated signalling and a further increase in IFN- $\gamma$ production. T-bet also prevents differentiation towards Th2 by suppressing the expression of the factors required for the Th2 subset differentiation process.

Moreover, Th2 differentiation implies concomitant TCR/IL-4 receptor signalling (and therefore the presence of IL-4 in the extracellular milieu), which induces STAT6-dependent signalling. STAT-6 signalling leads to the expression of GATA-3, a master regulator towards Th2 commitment. GATA-3 acts as a transcription factor and induces its own expression as it simultaneously causes epigenetic changes in the chromatin, which favours the expression of IL-4, IL-5 and IL-13. GATA-3 also suppresses the critical elements for the Th1 differentiation process (e.g., STAT-4 and IL-12R). Note that factors involved in the Th1 response negatively impact the Th2 response and vice-versa. This regulatory loop allows full differentiation towards one subset or the other once the decisional process has been initiated.

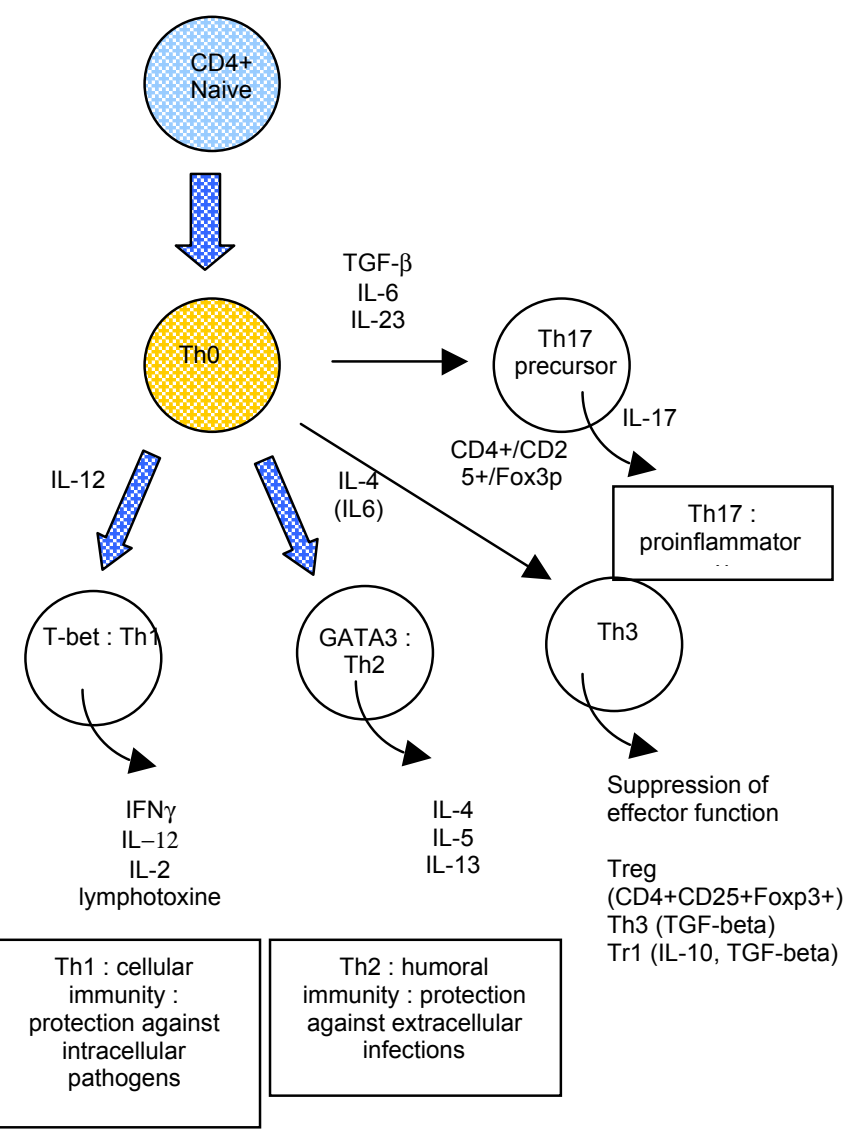

Figure 1. Differentiation model of CD4+ T helper cells adapted from Murphy et al. Nat Rev Immunol (2002) 2 :933-944 (Murphy and Reiner, 2002) and Korzenik et al. Nat Drug Discov (2006) 5 :197-209 (Korzenik and Podolsky, 2006)
To summarize, the IL-12 and IFN- $\gamma$ cytokines and the STAT-1, STAT-4 and T-bet transcription factors are associated with a Th1 response, whereas the IL-4, IL-5 and IL-13 and the STAT-6 and GATA-3 transcription factors are linked to a Th2 response (Murphy and Reiner, 2002). Other cytokines have been associated with Th1 type responses (e.g., IL-2, lymphotoxin) or Th2 type responses (e.g. IL-6, IL-9, IL-10), but their production does not necessarily characterize the Th1 or Th2 type response (Leonard, 2003).

Finally, the presence of a further subset of CD4+ T helper cells with pro-inflammatory properties, called Th17, was recently discovered. It is characterized by the production of IL-17 and differentiation by TGF- $\beta$ and IL- 6 cytokines (Bettelli et al., 2006; Harrington et al., 2006).

\section{Th1/Th2 balance}

The balance between Th1 and Th2 cytokine production can determine the direction and outcome of an immune response. A true balance between Th1 and Th2 profiles can be difficult to maintain, as Th1 and Th2 cells inhibit each other. The theory wants that the subclasses, Th1 and Th2, direct the immune answer towards the intracellular pathogen eradication (Th1) or towards the parasitic and extracellular infections (Th2). An answer exaggeratedly deviated towards Th1 is associated to chronic inflammatory diseases whereas an abnormal response of Th2 type characterizes the allergic reactions.

It is proposed that Th1 and Th2 cells can antagonize each other's action, either by blocking polarized maturation of the opposite cell type or by blocking its receptor functions. For example, IFN $\gamma$ produced by Th1 cells can block the proliferation of Th2 cells, and high concentration of IL-4 can impede the generation of Th1 from naive $T$ cells.

However, other immune cells can also intervene to block either Th1 or Th2 activity or both. They are the regulatory $T$ cells. Several subsets of $T$ cells with immunoregulatory properties with distinct phenotypes and distinct mechanisms of action have now been identified. These include the antigen-induced type $1 \mathrm{Tr}$ cells which secrete high levels of IL-10 and low to moderate levels of transforming growth factor (TGF $\beta$ ) (Groux et al., 1997) and type 3 T cells (Th3) (Chen et al., 1994) which primarily secrete TGF $\beta$ as well as thenaturally-occuring , thymic-derived CD4+CD25+ T cells (Treg), that inhibit immune response through cellcell contact (Shevach, 2000).

\section{The mucosal immune system}

Most of our encounters with antigens or infectious agents occur at mucosal surfaces, which include the surface lining the gastrointestinal, respiratory and genitourinary tracts (Delves and Roitt, 2000). Since probiotics are usually absorbed orally, they are thus ideally suited to influence the immune response at the "mucosal frontier" of the gastrointestinal tract, representing more than $300 \mathrm{~m}^{2}$. 
Well known for its nutrition function (digestion of food and the assimilation of the nutrients), the intestinal system is also able to protect us from the pathogenic microbes. It contains more than 100 million neurons, secretes at least 20 neurotransmitters identical to those produced by the brain (serotonin, noradrenalin, dopamine...), produces 70 to $85 \%$ of the immune cells of the organism, lodges 100000 billion bacteria. All these compounds, present locally, are in relationship to the whole of the organism.

Although the immune response of the intestinal mucosa exhibits several features in common with the immune responses produced by other organs, it is characterized by certain distinctive properties. The immune properties of the digestive mucosa are provided by the GALT (Gut-associated lymphoid tissue). The GALT is composed of lymphoid aggregates, including the Peyer's patches (located mainly in the small intestinal distal ileum), where induction of immune responses occurs, and mesenteric lymphoid nodes. In addition, there are large amounts of immune-competent cells in the lamina propria and the mucosal epithelium. The intestine also protects us from pathogens because its epithelium is covered by mucus and avoids any direct contact with the micro-organisms.

The intestinal immune system must encounter all antigens in order to determine which ones require an immune response and which ones can be safely tolerated. Intestinal antigens are acquired through different mechanisms. First, enterocytes transport antigens from the intestinal lumen to the lamina propria. Enterocytes can even act as APCs, since these cells express MHC class II molecules as well. Antigen sampling also occurs in Peyer's patches, where a specialized epithelium, known as the follicularassociated epithelium (FAE), covers one or many lymphoid follicles composed of $B$ and $T$ cells, DCs and macrophages. The FAE is made up of enterocytes and $M$ cells. Differing from enterocytes by the absence of a brush border and by the absence of mucus production, $M$ cells have the important task of transporting antigens across the epithelium to the lymphoid follicle, a structure commonly referred to as the dome epithelium (DE). An enormous variety of pathogens take advantage of the properties of $M$ cells to penetrate the intestinal mucosa and invade the host. Finally, it has been shown that DCs, using their dendrites, also act as guard cells in the intestinal lumen without disturbing the integrity of their tight surface junctions. The intestinal epithelium is also characterized by the presence of intraepithelial lymphocytes (IEL) located between the enterocytes. Most IELs have a CD8+ T cell phenotype. Within the lymphocyte subsets that populate the intestinal mucosa are found CD4+ T helper cells (Th1 and Th2), cytotoxic CD8+ $T$, and a wide variety of regulatory $T$ cells such as Th3, Tr1 and thymic-derived CD4+CD25+.

With the help of the CD4+ T cells and cytokines (IL10 and TGF- $\beta$ ) present in the gut, B cells differentiate into dimeric IgA isotype antibody-secreting plasma cells. The dimeric IgAs are then secreted in the intestinal lumen by the enterocytes, where they help bind antigens and neutralize viruses, bacteria and toxins, thereby contributing to protect the host against infectious agents and toxic substances (Lefrancois and Puddington, 2006;
Macdonald and Monteleone, 2005; Mestecky, 2003; Mowat, 2003).

The intestinal immune system is the subject of complex regulation processes allowing the elimination of pathogenic micro-organisms, while maintaining a tolerance towards food antigens and endogenous flora. Butyrate as well as other products resulting from colic fermentation, could take part in this regulation. In chronic intestinal inflammatory diseases (CIID) such as Crohn's disease (Macdonald and Monteleone, 2005 ; MacDonald et al., 2000) and hemorrhagic rectocolitis (HRC), a deregulation of the intestinal immune system would lead to an inadequate response against one or more endoluminal antigens. An imbalance between Th1 (IL-2, IFN $\gamma$, TNF $\alpha$ ) and Th2 responses (IL-4, IL-5, IL-10) was described in human and also in animal models. This led to a chronic inflammatory answer characterized by the production of pro-inflammatory cytokines (IL-1, IL-6, TNF $\alpha$ ).

It has been proposed that the mucosal immune system normally maintains itself in a state that favours tolerance and IgA production, showing a slight deviation towards the Th2 response over Th1 response. Nevertheless, this deviation is not absolute, since some chronic inflammatory bowel diseases such as ulcerative colitis are somewhat Th2-driven, whereas others like Crohn's disease show a predominantly Th1-mediated cytokine profile (Korzenik and Podolsky, 2006; Strober et al., 2002 ). Thus, the cytokine profile plays an important role in the maintenance of intestinal immune homeostasis.

\section{Probiotic interaction - intestinal epithelium}

Our intestine is colonized by a great number of microorganisms living in the intestinal area and supporting a variety of physiological functions. The intestinal microbial colonization occurs by stages. It starts at birth and continues during the subsequent phases of life to form an individual intestinal microbiota. This process facilitates the formation of a physical and immunological barrier between the environment and us, helping to maintain the gastro-intestinal tract in health. The composition of the commensal colon microbiota is probably influenced by the combination of food practices and other factors like the geographical localization, various levels of hygiene or various climates.

The host-microbe interaction is of primary importance during neonatal period. The establishment of a normal microbiota provides the most substantial antigenic challenge to the immune system, thus helping the GALT maturation. At birth, the intestinal immune system is inexistent and will develop at the same time as the intestinal microbiota. It becomes more and more complex as food practices change. Around two years old of age, the intestinal microbiota seems comparable in composition with that of an adult and the intestinal immune system is considered mature. The intestinal microbiota contributes to the anti-inflammatory character of the intestinal immune system.

Several immunoregulatory mechanisms, including regulatory cells, cytokines, apoptosis among others, participate in the control of immune responses by 
preventing the pathological processes associated with excessive reactivity. Many inflammatory diseases are due to a lack of these mechanisms. An interesting premise for probiotic physiological action is their capacity to modulate the immune system. Consequently, many studies have focused on the effects of probiotics on diverse aspects of the immune response.

Following consumption of probiotic products, the interaction of these bacteria with intestinal enterocytes initiates a host response, since intestinal cells produce various immunomodulatory molecules when stimulated by bacteria.

The interaction between probiotic strains and enterocytes is important for the controlled production of cytokines and chemokines secreted by epithelial cells (Table 1). Indeed, it has been shown that some probiotic organisms can modulate the in vitro expression of proand anti-inflammatory molecules in a strain-dependent manner. For instance, Lactobacillus sakei induces the expression of IL-1 $\beta, I L-8$ and TNF- $\alpha$, whereas $L$. johnsonii stimulates the production of TGF- $\beta$ in Caco- 2 cells. This process appears to require cross-talk between the epithelial cells and the underlying leucocytes (Haller et al., 2000).

The interaction of probiotics and Peyer's patch $M$ cells has been established, and the importance of these cells in the transport of antigens across the intestinal epithelium has received considerable attention (Claassen et al., 1995; Muscettola et al., 1994). A study using fluorescent-tagged lactobacilli in mice showed that, 10 minutes after oral feeding of probiotics, fluorescence was detected in immune cells in Peyer's patches and the lamina propria in the small intestine as well as in immune cells in the crypt and lymph nodules in the colon. In addition, fluorescence associated with the presence of $L$. casei was observed in Peyer's patches for about two to three days (Galdeano and Perdigon, 2004). These findings demonstrate that probiotics, or at least their bacterial products, can access the intestinal mucosal immune system, persist for a certain amount of time, and initiate a specific immune response.

\section{Probiotics and innate immunity}

\section{Macrophages and phagocytic capacity}

Many probiotic strains can influence innate defence mechanisms such as phagocytosis (Table 2). In 1988, Perdigon et al. showed that $L$. acidophilus and $L$. casei performed a systemic immunostimulation by increasing the phagocytosis capacity of murine peritoneal macrophages (Perdigon et al., 1988). In addition, it was demonstrated that $L$. acidophilus La1 increased the phagocytosis capacity of leucocytes isolated from the blood of humans who had consumed probiotics, which is consistent with the adhesion potential of this bacterium (Donnet-Hughes et al., 1999; Schiffrin, 1994; Schiffrin et al., 1997). Meanwhile, bacteria like Bifidobacterium. lactis $\mathrm{Bb} 12$, which exhibit slightly less adhesion, also substantially increased phagocytosis (Schiffrin et al., 1997). Moreover, B. lactis HN019 considerably augmented the phagocytosis of peripheral blood mononuclear cells (PBMC) (Arunachalam et al., 2000).
A further study showed that a milk product containing L. rhamnosus GG significantly up-regulated the expression of important phagocytosis receptors like CR1, CR3, Fc $\gamma$ RIII and FC $\alpha R$ in the neutrophils of healthy individuals (Pelto et al., 1998). It is noteworthy that patients suffering from milk-hypersensitivity also showed increased expression of these receptors and that the expression of these molecules was reduced when they consumed milk containing $L$. rhamnosus GG. The study authors concluded that $L$. rhamnosus GG stimulates immune response in the phagocytes of healthy individuals and inhibits phagocytosis in allergic individuals (Pelto et al., 1998). L. johnsonii La1 was shown to increase the respiratory burst of phagocytes isolated from human blood following probiotic consumption (Donnet-Hughes et al., 1999). Moreover, the ex vivo phagocytic activity of mononuclear and polymorphonuclear phagocytes was enhanced following consumption of $L$. rhamnosus $\mathrm{HN} 001$ and $B$. lactis HN109 (Gill et al., 2001b; Sheih et al., 2001).

\section{Natural Killer (NK)}

Probiotic organisms also regulate the activity of natural killer (NK) cells (Table 2). It was shown that $L$. rhamnosus HN001 and B. lactis HN109 significantly increased the cytotoxic potential of NK cells, and that this property decreased after cessation of probiotic consumption, although it remained above baseline (Gill et al., 2001a; Sheih et al., 2001). It appears that the use of the probiotic $L$. casei subsp. casei in combination with dextran also enhances the efficiency of NK cell activity. This property may be linked to intestinal epithelial cell production of IL-15, an important cytokine for NK cells (Ogawa et al., 2006). The use of $L$. casei Shirota was also able to enhance NK cell activity and this activity was correlated to an IL-12 production, another cytokine implicated in NK cells activity (Takeda et al., 2006). These studies suggest that probiotics may play a major role in boosting the immunosurveillance of NK cells, thus helping to prevent the development of malignant tumours.

Furthermore, it seems that the positive effects of probiotics on phagocytosis and NK cell function may be greater in immune deficient elderly persons (Gill et al., 2001a; Gill et al., 2001b). Thus, consumption of probiotics may favour innate immune defences in aging individuals.

Finally, oral intake of $L$. fermentum CECT5716 is able to potentate the immunologic response of an antiinfluenza vaccine by increasing the proportion of NK cells (Olivares et al., 2007).

\section{Enterocytes and cytokines production}

A study demonstrated that the probiotic $E$. coli Nissle 1917 induces the production of IL-8 in HT-29 cells (Human colonic adenocarcinoma cells that are able to express differentiation features characteristic of mature intestinal cells such as the goblet cells), whereas the lactobacilli and bifidobacteria contained in the probiotic VSL\#3 cannot (Lammers et al., 2002; Otte and Podolsky, 2004). L. plantarum 299v also increases IL-8 mRNA levels in HT-29 epithelial cells previously stimulated by TNF- $\alpha$. This IL- 8 production requires the 
presence of live bacteria, and was not observed when adhesion between L. plantarum 299v and HT-29 cells was inhibited (McCracken et al., 2002). This study did not provide any explanation for the evidence that, although IL-8 mRNA clearly increased in the presence of TNF- $\alpha$, the secretion of IL- 8 in the supernatant actually decreased. Nevertheless, this is a landmark study because it suggests that probiotic adhesion to intestinal cells is an important component in their action mechanism.

Quality and dose of probiotic preparations may also impact the IL-8 production by enterocytes. When incubated with higher doses of $L$. rhamnosus GG, Caco2 cells produce less IL- 8 (induced by TNF- $\alpha$ stimulation) (Zhang et al., 2005). IL-8 appears to be a major cytokine produced by enterocytes following an encounter with a probiotic organism. The IL-8 cytokine primarily functions as a neutrophil chemoattractant. Probiotic strains differ in their capacity to augment IL-8 expression, however, and some strains seem to rather decrease epithelial-cell production of IL-8. For instance, L. reuteri exerts an antiinflammatory effect on T84 and HT-29 cell lines by diminishing their IL-8 production. $L$. reuteri also induces the production of nerve growth factor (NGF), an antiinflammatory molecule. L. reuteri also requires the presence of live bacterial cells with intestinal cell for its adhesion capacity effect (Ma et al., 2004). Since all these findings were based on the use of cell lines as experimental models, they do not necessarily represent the actual in vivo situation.

Aside from IL-8, enterocytes can excrete other cytokines such as IL- 6 in the presence of probiotic organisms, as demonstrated with more physiological models. By studying rats whose intestinal tract are colonized by only one organism, B. lactis Bb12, Ruiz et al. showed that intestinal epithelial cells can produce IL6 up to five days following bacterial colonization (Ruiz et al., 2005). After co-incubation of primary intestinal cells with probiotics in mice, it was found that $L$. casei CRL 431 and $L$. helveticus R389 also increased IL-6 secretion (Vinderola et al., 2005). L. casei subs. casei, L. paracase $i$ and $L$. acidophilus probiotics induced production of IL-15, a multifunctional cytokine, in Caco-2 cells as well (Ogawa et al., 2006).

Finally, analysis of mRNA microarrays revealed that $L$. casei DN-114 01 reduced the expression of chemokines that attract macrophages (CXCL1 and CXCL2) and DCs (CCL20) in Caco-2 cells exposed to Shigella flexneri (Tien et al., 2006). It was also found that some lactobacilli strains modulated the IFN- $\gamma$ induced expression of HLA-DR, CD45 and ICAM-1 (intercellular adhesion molecule-1) on HT-29 cells (Delneste et al., 1998). Lastly, it was shown that L. rhamnosus GG inhibited cytokine induced apoptosis (TNF- $\alpha$, IL- $1 \alpha$ or IFN- $\gamma$ ) of intestinal epithelial cells by activating the antiapoptotic molecule AKT/protein kinase $B$ and by inhibiting the pro-apoptotic p38/mitogen-activated protein kinase signalling pathway (Yan and Polk, 2002).

Taken together, these studies suggest that the interaction of probiotic bacteria with the intestinal epithelium is a key determinant for cytokine production by enterocytes, and probably the initiating event in probiotic immunomodulatory activity, as it occurs prior to the encounter with the immune system cells (Table 1).

Table 1. Cytokines produced following the interaction of probiotics with the intestinal epithelium

\begin{tabular}{|c|c|c|c|}
\hline Organism & $\begin{array}{l}\text { Cytokines/ } \\
\text { Chemokines }\end{array}$ & Cells & References \\
\hline L. sakei & $\begin{array}{l}\mathrm{IL}-1 \beta, \mathrm{IL}-8, \mathrm{TNF}-\alpha \\
\text { (pro-inflammatory, } \\
\text { apoptosis inducer) }\end{array}$ & Caco-2 & $\begin{array}{l}\text { (Haller et al., } \\
2000)\end{array}$ \\
\hline L. johnsonii & $\begin{array}{l}\text { TGF- } \beta \\
\text { (pro-inflammatory } \\
\text { Th17 inductor) }\end{array}$ & Caco-2 & $\begin{array}{l}\text { (Haller et al., } \\
2000)\end{array}$ \\
\hline $\begin{array}{l}\text { E. coli Nissle } \\
1917\end{array}$ & $\begin{array}{l}\text { IL-8 } \\
\text { (Pro-inflammatory, } \\
\text { neutrophiles } \\
\text { stimulator, bactericid } \\
\text { activity by oxygen } \\
\text { activation) }\end{array}$ & T-84, HT-29 & $\begin{array}{l}\text { (Lammers et } \\
\text { al., 2002); (Otte } \\
\text { and Podolsky, } \\
\text { 2004) }\end{array}$ \\
\hline L. reuteri & $\begin{array}{l}\text { NGF } \\
\text { (nerve growth factor) }\end{array}$ & T84, HT-29 & $\begin{array}{l}\text { (Ma et al., } \\
2004 \text { ) }\end{array}$ \\
\hline B. lactis $\mathrm{Bb} 12$ & $\begin{array}{l}\text { IL-6 } \\
\text { (Pro-inflammatory, } \\
\text { growth factor of B } \\
\text { cells, support the } \\
\text { production of blood } \\
\text { plates) }\end{array}$ & $\begin{array}{l}\text { Primary } \\
\text { intestinal } \\
\text { epithelial cells, } \\
\text { Mode-k }\end{array}$ & $\begin{array}{l}\text { (Ruiz et al., } \\
\text { 2005) }\end{array}$ \\
\hline L. rhamnosus GG & IL-8 & Caco-2 & $\begin{array}{l}\text { (Zhang et al., } \\
\text { 2005) }\end{array}$ \\
\hline $\begin{array}{l}\text { L. casei DN-114 } \\
001\end{array}$ & $\begin{array}{l}\text { CXCL1, CXCL2, } \\
\text { CCL20 } \\
\text { (attract macrophages) }\end{array}$ & Caco-2 & $\begin{array}{l}\text { (Tien et al., } \\
\text { 2006) }\end{array}$ \\
\hline L. casei CRL 431 & IL-6 & $\begin{array}{l}\text { Primary } \\
\text { intestinal } \\
\text { epithelial cells }\end{array}$ & $\begin{array}{l}\text { (Vinderola et } \\
\text { al., 2005) }\end{array}$ \\
\hline $\begin{array}{l}\text { L. helveticus } \\
\text { R389 }\end{array}$ & IL-6 & $\begin{array}{l}\text { Primary } \\
\text { intestinal } \\
\text { epithelial cells }\end{array}$ & $\begin{array}{l}\text { (Vinderola et } \\
\text { al., 2005) }\end{array}$ \\
\hline $\begin{array}{l}\text { L. casei subsp. } \\
\text { casei }\end{array}$ & $\begin{array}{l}\text { IL-15 } \\
\text { (NK cells activation) }\end{array}$ & Caco-2 & $\begin{array}{l}\text { (Ogawa et al., } \\
2006 \text { ) }\end{array}$ \\
\hline
\end{tabular}

Table 2. Probiotic influence on different immune functions

\begin{tabular}{|c|c|c|}
\hline $\begin{array}{l}\text { Immune system } \\
\text { effect }\end{array}$ & Organism & References \\
\hline $\begin{array}{l}\text { Increased } \\
\text { phagocytosis } \\
\text { capacity }\end{array}$ & $\begin{array}{l}\text { L. acidophilus } \\
\text { (johnsonii) La1 } \\
\text { L. casei } \\
\text { B. lactis Bb12 } \\
\text { B. lactis HN019 } \\
\text { L. rhamnosus GG } \\
\text { L. rhamnosus } \\
\text { HN001 }\end{array}$ & $\begin{array}{l}\text { (Arunachalam et al., } \\
\text { 2000; Donnet-Hughes } \\
\text { et al., 1999; Pelto et } \\
\text { al., 1998; Perdigon et } \\
\text { al., 1988; Schiffrin, } \\
\text { 1994; Schiffrin et al., } \\
\text { 1997) }\end{array}$ \\
\hline $\begin{array}{l}\text { Increased NK cell } \\
\text { activity }\end{array}$ & $\begin{array}{l}\text { L. rhamnosus } \\
\text { HN001 } \\
\text { B. lactis HN109 } \\
\text { L. casei subsp. } \\
\text { casei + dextran }\end{array}$ & $\begin{array}{l}\text { (Gill et al., 2001a; } \\
\text { Ogawa et al., 2006; } \\
\text { Sheih et al., 2001) }\end{array}$ \\
\hline $\begin{array}{l}\text { Stimulation of } \lg \mathrm{A} \\
\text { production }\end{array}$ & $\begin{array}{l}\text { B. bifidum } \\
\text { L. acidophilus } \\
\text { (johnsonii) La1 } \\
\text { L. casei rhamnosus } \\
\text { GG } \\
\text { B. lactis Bb12 }\end{array}$ & $\begin{array}{l}\text { (Fukushima et al., } \\
\text { 1998; Ibnou-Zekri et } \\
\text { al., 2003; Isolauri et al., } \\
\text { 1995; Kaila et al., } \\
\text { 1995; Link-Amster et } \\
\text { al., 1994; Majamaa et } \\
\text { al., 1995; Park et al., } \\
\text { 2002) }\end{array}$ \\
\hline $\begin{array}{l}\text { Suppression of } \\
\text { lymphocyte } \\
\text { proliferation } \\
\text { Induction of } \\
\text { apoptosis }\end{array}$ & $\begin{array}{l}\text { L. rhamnosus GG } \\
\text { L. casei GG } \\
\text { B. lactis } \\
\text { L. acidophilus } \\
\text { L. delbrueckii subsp. } \\
\text { bulgaricus } \\
\text { S. thermophilus } \\
\text { L. paracasei } \\
\text { E. coli Nissle } 1917\end{array}$ & $\begin{array}{l}\text { (Carol et al., 2006; } \\
\text { Pessi et al., 1999; } \\
\text { Sturm et al., 2005; von } \\
\text { der Weid et al., 2001) }\end{array}$ \\
\hline $\begin{array}{l}\text { Increased cell- } \\
\text { mediated immunity }\end{array}$ & L. casei Shirota & (de Waard et al., 2003) \\
\hline
\end{tabular}




\section{Probiotics and adaptive immunity}

\section{IgA production}

Many probiotic strains are apparently well able to stimulate the production of $\lg A$ by $B$ cells, which help maintain intestinal humoral immunity by binding to antigens, thereby limiting their access to the epithelium (Table 2). Study subjects who consumed fermented milk containing $B$. bifidum and $L$. acidophilus La1 following vaccination against Salmonella typhi Ty21 showed a significant increase in IgA serum concentration (LinkAmster et al., 1994).

In addition, children 2 to 5 years old who received $L$. rhamnosus GG concomitantly with a rotavirus vaccination showed an increased number of $\lg A$ secreting cells (Isolauri et al., 1995). Moreover, $L$. rhamnosus GG dramatically increased IgA seroconversion during the remission phase in children suffering from acute rotavirus-induced diarrhoea (Kaila et al., 1995; Majamaa et al., 1995). One such study also reported that only live probiotics induced the $\lg A$ specific response, which helps prevent reinfection (Kaila et al., 1995). Bifidobacteria can also promote IgA production, since children who consumed a preparation containing $B$. lactis $\mathrm{Bb} 12$ for a few months after receiving their polio vaccine showed an increase in the total amount of IgA in the feces, and more particularly, antipoliovirus $\lg A$ (Fukushima et al., 1998).

Some of these studies have emphasized the fact that total serum IgA level is enhanced following oral consumption of probiotics. However, there is a basic difference between the $\lg A$ found in the serum and those present in the intestine, as the latter have a dimeric or polymeric form and contain a secretory component required for export. Thus, measuring serum IgA may not reflect actual digestive tract conditions. Accordingly, Park et al. studied IgA production by intestinal mucosal lymphoid cells in mice. They showed that $B$. bifidum significantly induced IgA production in Peyer's patches and mesenteric lymph nodes, and that optimal secretion was obtained with probiotics encapsulated in alginate microparticles. Surprisingly, rather than inducing a specific humoral immune response, $B$. bifidum apparently had a more systemic immune effect (Park et al., 2002).

Another study demonstrated that a peptide fraction derived from $L$. helveticus-fermented milk contributed to induce local mucosal and systemic $\lg \mathrm{A}$ immune responses in mice that were infected with $E$. coli O157:H7. Results indicated that the metabolites produced by probiotics might influence host immunity, and would therefore be highly appropriate for use in a food matrix (Leblanc et al., 2004).

Moreover, it appears that the influence of probiotics on humoral immunity may be partially determined by the colonizing properties of the probiotic organisms. Indeed, although both $L$. johnsonii and $L$. paracasei displayed similar adhesion properties to Caco-2 cells, L. johnsonii was a better colonizer in the intestines of gnotobiotic mice, and a more efficient inducer of intestinal $\lg A$ production than L. paracasei (Ibnou-Zekri et al., 2003).

\section{Dendritic cells and Treg cells}

Antigen presenting cells (APCs), and more particularly DCs, are key players in both the determination of the Th1/Th2 balance and the development of tolerance. There are several types of DCs, and the literature indicates that DCs can orient the immune response according to activation environment, specific DC subset, or their activation kinetics (Moser, 2003). Given the important role of DCs in the orchestration of the immune response, it has been hypothesized that probiotic organisms modulate the immune response by influencing DC maturation.

DCs can instruct naive CD4+ T cells to differentiate into Th1, Th2 or even Th3. Using DCs derived from human monocytes, Braat et al. showed that DCs that were allowed to mature in the presence of $L$. rhamnosus reduced both the proliferation of $T$ cells (naive and memory) and the secretion of IL-2, IL-4 and IL-10 upon anti-CD3/anti-CD28 stimulation. In addition, using $T$ cells isolated from healthy and Crohn's patients, it was found that oral consumption of $L$. rhamnosus induced the same unresponsive state in CD4+ Th1 and Th2 cells in vivo (Braat et al., 2004).

A study examined bone marrow-derived murine DCs exposed to different irradiated lactobacilli ( $L$. reuteri, $L$ plantarum Lb20, L. casei subsp. alactus, $L$. plantarum $299 \mathrm{v}$ and L. johnsonii La1). All the strains were able to induce DCs maturation. L. casei subsp. alactus has been characterized as an inducer of pro-inflammatory cytokines (IL-12, IL6, TNF- $\alpha$ ) in DCs, whereas $L$. reuteri appears to be a poor stimulator of $\mathrm{IL}-12$ in DCs. Surprisingly, $L$. reuteri inhibits the production of IL-12, IL6 and TNF- $\alpha$ and the expression of B7.2 (CD86) in DCs induced by $L$. casei subsp. alactus, while maintaining steady DC production of IL-10 (Christensen et al., 2002). This study emphasizes that the differentiation process for DC of the gut can be modulated according to composition of gut microflora, including ingested probiotics, alone or in combination.

Another study in mice demonstrated that the probiotic preparation VSL \#3 increased the expression of B7.1 (CD80), B7.2, CD40 and MHC class II molecules. In addition, when the DCs were incubated in the presence of the probiotics, they were unable to induce $T$ cell proliferation. A substantial increase in IL-10 levels was however observed in the supernatant when DCs were incubated with the probiotics for three days (Drakes et al., 2004). These results demonstrate that probiotics possess the ability to modulate DC surface phenotype and cytokine release by blood DCs. Regulation of DC cytokines by probiotics may contribute to the benefit of these molecules in treatment of intestinal diseases. However, the DCs isolated from the blood most probably differed from those derived from bone marrow, and consequently those present in the intestine.

Hart et al. (2004) compared changes in the expression of DC differentiation markers and cytokine production upon incubation with VSL \#3 in human DCs obtained from blood or intestinal tissue following biopsy. VSL\#3 diminished proinflammatory effects of LPS by 
decreasing LPS induced production of IL-12 while maintaining IL-10 production. VSL\#3 was also a potent inducer of IL-10 by DCs from blood and intestinal tissue, and inhibited generation of Th1 cells. Of all the probiotics in the VSL \#3 preparation, bifidobacteria are the most potent IL-10 inducers. They are also more effective in decreasing surface expression of B7.1 (CD80) in DCs, and they inhibit T cell production of IFN- $\gamma$ as well (Hart et al., 2004).

It has been suggested that some probiotics influence monocyte-derived DCs to drive the development of Treg cells. These Treg cells produced increased levels of IL10. Thus, when human monocyte-derived DCs are incubated in the presence of $L$. reuteri and $L$. casei, they induce $T$ cell differentiation into regulatory $T$ cells that produce large amounts of IL-10. L. plantarum, on the other hand, is incapable of inducing the regulatory $\mathrm{T}$ cell differentiation. It appears that the ability of these probiotics to induce regulatory T cells by the DCs is due to their ability to bind to the lectin dendritic cell (DCspecific intercellular adhesion molecule 3-grabbing nonintegrin) (DC-SIGN) (Smits et al., 2005).

In addition, in an animal model of inflammatory bowel disease caused by Th1 cells, the probiotic VSL \#3, when administered to mice for three weeks, reduced colitis severity. This beneficial effect was associated with the production of IL-10, and in particular, the generation of greater numbers of Treg cells expressing TGF- $\beta$ at the surface of the cell membrane of the lamina propria. It is significant that the transfer of mononucleated lamina propria cells from mice treated with VSL\#3 to naive mice impeded colitis development, and that this effect depended on regulatory CD4+ cells, since the depletion of regulatory CD4+ T cells impeded the very protector effect generated by the transfer (Di Giacinto et al., 2005).

Finally, it was shown that the probiotic $L$. paracasei NCC2461 induced the development of a CD4+ T cell subset characterized by a low proliferation potential but a marked ability to secrete IL-10 and TGF- $\beta$. This subset is very similar to a population of regulatory cells that participate in the oral tolerance process required to maintain gastro-intestinal stability (von der Weid et al., 2001). L. paracasei NCC2461 also participates in the $\beta$ lactoglobulin (BLG) oral tolerance process in mice, attributable to the hydrolysis of BLG into peptides, which stimulate the production of IL-10 (Prioult et al., 2003; Prioult et al., 2004). Thus, metabolites generated by the breakdown of food by probiotic organisms may have immunomodulatory effects.

Taken together, these studies indicate that many probiotic organisms act as anti-inflammatory agents by influencing DCs to induce a non-response state, more particularly by encouraging the development of $T$ cells with immunoregulatory properties (Table 3).

Meanwhile, another study suggested that some lactobacilli strains promote DCs to regulate $\mathrm{T}$ cell responses toward Th1 pathway by stimulation the secretion of high levels of IL-12 and IL-18, but not IL-10 (Mohamadzadeh et al., 2005). Almost all strains belonging to the Lactobacillus casei group are able to induce high level of IL-12 via macrophages stimulation
(Shida et al., 2006). Another study suggested that $B$. longum stimulates murine colonic DCs in mice to produce not only IL-10 but also IL-12 (Rigby et al., 2005). These results show that even if the cytokines profiles secreted by DCs is more often directed toward an anti-inflammatory answer, it remains strains dependent.

Table 3. Some probiotics and their effects on DC maturation

\begin{tabular}{|c|c|c|}
\hline $\begin{array}{l}\text { Organi } \\
\text { sm }\end{array}$ & Effect & Reference \\
\hline $\begin{array}{l}\text { L. } \\
\text { rhamnosus }\end{array}$ & $\begin{array}{l}\downarrow \quad \text { proliferation and } \\
\text { activation of T cells }\end{array}$ & $\begin{array}{l}\text { (Braat et al., } \\
2004)\end{array}$ \\
\hline reuteri & $\begin{array}{l}\quad \downarrow I L-12, I L-6, \text { TNF-a, } \\
\text { inhibits the expression of } \\
\text { B7.2, induces regulatory T cell } \\
\text { differentiation }\end{array}$ & $\begin{array}{l}\text { (Christensen et } \\
\text { al., 2002; Smits et al., } \\
\text { 2005) }\end{array}$ \\
\hline $\begin{array}{l}\text { L. casei } \\
\text { subsp. } \\
\text { Alactus }\end{array}$ & $\uparrow \mathrm{IL}-12, \mathrm{IL}-6, \mathrm{TNF}-\mathrm{a}$ & $\begin{array}{l}\text { (Christensen et } \\
\text { al., 2002) }\end{array}$ \\
\hline VSL \#3 & $\begin{array}{l}\uparrow \quad D C \text { maturation, } \downarrow \\
\text { lymphocyte proliferation, } \downarrow \text { IL- } \\
12, \uparrow \text { IL-10, } \downarrow \text { Th1 }\end{array}$ & $\begin{array}{l}\text { (Drakes et al., } \\
\text { 2004; Hart et al., } \\
\text { 2004) }\end{array}$ \\
\hline $\begin{array}{c}\text { B. } \\
\text { longum }\end{array}$ & $\uparrow$ IL-10, IL-12 & $\begin{array}{l}\text { (Rigby et al., } \\
\text { 2005) }\end{array}$ \\
\hline L. casei & $\begin{array}{l}\text { Induces regulatory } \mathrm{T} \text { cell } \\
\text { differentiation }\end{array}$ & $\begin{array}{l}\text { (Smits et al., } \\
2005)\end{array}$ \\
\hline $\begin{array}{l}\quad L . \\
\text { gasseri, } \\
L . \\
\text { johnsonii } \\
\text { and } \\
L . \\
\text { reuteri }\end{array}$ & $\begin{array}{l}\text { 个IL-12 and IL-18, but not } \\
\mathrm{IL}-10\end{array}$ & $\begin{array}{l}\text { (Mohamadzadeh } \\
\text { et al., 2005) }\end{array}$ \\
\hline L. casei & $\begin{array}{l}\text { 个IL-12 via macrophages } \\
\text { stimulation }\end{array}$ & $\begin{array}{l}\text { (Shida et al., } \\
\text { 2006) }\end{array}$ \\
\hline
\end{tabular}

\section{Th1/Th2 balance}

Most of the knowledge on how probiotics affect the immune system comes from profile analyses of cytokines produced by a wide variety of immune cells in response to the consumption of probiotic organisms. It has been proposed that probiotics exert an immunomodulatory effect by influencing the cytokine production of the various effecter cells in the intestine and especially enterocytes. Studies investigating cytokine production by immune-regulating cells submitted to probiotic strains have shown that probiotics can influence the cytokine profile produced. However, the effect appears to be strain-dependent, and depending on the strain, either pro-inflammatory or antiinflammatory effects on the immune system have been observed. Moreover, the interaction between probiotic strains and enterocytes is important for the controlled production of cytokines and chemokines secreted by epithelial cells (Table 1).

In view of the importance of the Th1/Th2 paradigm to our understanding of the immune response, it has been suggested that consumption of probiotic products could produce an immunomodulatory effect by disrupting the $T$ CD4+ and helper cell differentiation process through upsetting the Th1/Th2 equilibrium, among others. 

effect

Th1/Th2 alteration toward Th1: Pro-inflammatory

The lactobacilli $L$. plantarum, $L$. lactis, $L$. casei and $L$. rhamnosus GG all seem to inhibit Th2 response in allergic patients. These bacteria significantly reduce IL-4 and IL-5 production by peripheral blood mononuclear cells (PBMC) when human cells are preincubated with lactobacilli prior to stimulation with specific allergens. This mechanism requires the presence of monocytes and is dependent on Th1 cytokines (IL-12 and IFN- $\gamma$ ) (Pochard et al., 2002).

Using a food allergy model to study Th2 response in mice, Shida et al. showed that peritoneal injection of heat-killed $L$. casei Shirota induced an increase in serum IL-12 and a skewing of the cytokine profile from Th2 to Th1 (less IL-4 and IL-5 and more IFN-g ). This caused lower secretions of $\operatorname{lgE}$ and $\operatorname{lgG} 1$ antibodies by splenocytes, thereby preventing systemic anaphylactic reaction (Shida et al., 2002). This phenomenon was specific to $L$. casei Shirota, since no effect was found with injection of $L$. johnsonii JCM 2012. A drawback to this study is that the authors injected probiotic organisms into the peritoneum, which in no way reflects the real-life setting of the ingested probiotic organisms. In a study using a mouse model of lactoglobulin tolerance, Prioult et al. (2003) provide evidence that probiotics modulate the oral tolerance response to the milk protein and that effect is also strain-dependant (Prioult et al., 2003).

A double-blind clinical study in children who were allergic to cow's milk also showed that the administration of $L$. rhamnosus GG for four weeks increased IFN- $\gamma$ production in PBMCs after stimulation with antiCD3/anti-CD28. At the same time, it suppressed secretion of IL-4, normally produced in large quantities after stimulation of the CD4+ T cells in allergic children (Pohjavuori et al., 2004). This Th2 response inhibition by L. rhamnosus GG can be explained by the presence of bacterial enzymes, which degrade casein in order to generate metabolites that influence the Th1/Th2 balance. In fact, a study on allergic patients demonstrated that casein degraded by this probiotic organism reduced the production of IL- 4 by bloodderived $T$ cells after in vitro stimulation with anti-CD3 antibodies (Sutas et al., 1996a). These studies suggest that some probiotics function to skew the immune response towards Th1.

Many laboratories have observed that probiotic strains exercise a pro-inflammatory effect by stimulating the production of immunostimulatory cytokines. Probiotics can also increase the production of IFN- $\alpha$. It was found that ingested $L$. brevis subsp. coagulans (Labre) and B. lactis HN019 induced the production of IFN- $\alpha$ by subjects' PBMCs (Arunachalam et al., 2000; Kishi et al., 1996). In this way, probiotics can contribute to the inflammatory response. Miettinen et al. demonstrated that $L$. rhamnosus E509, $L$. rhamnosus $G G$ and $L$. bulgaricus $\mathrm{E} 585$ strongly induced productions of IL-1 13, IL-6, IL-18 and TNF-a in PBMCs and induced a moderate increase in both RNA and protein production of IL-12 and IL-10 (Miettinen et al., 1998). However, other studies suggested that live probiotic bacteria may not be required to influence the immune system (Amrouche, 2006; Pessi et al., 1999).
Using immunohistochemical analyses of mice intestines, it was shown that orally administered probiotics also influenced local production of proinflammatory cytokines. Thus, productions of TNF- $\alpha$, IL2 and IL-1 $\beta$ were enhanced when $L$. reuteri ML1 and $L$. brevis ML12 were ingested (Maassen et al., 2000). $L$. casei, $L$. delbrueckii subsp. bulgaricus and $L$. acidophilus also induced an increase in producer cells for TNF-a and IFN- $\gamma$, whereas only $L$. acidophilus increased the number of IL-2 and IL-12 producing cells. Finally, both $L$. delbrueckii subsp. bulgaricus and $L$. casei induced an increase in the number of IL-4 and IL-10 producing cells (Perdigon et al., 2002). These two studies make a strong argument for the existence of a wide variability in the strains that modulate local intestinal cytokine production. Finally, Miettinen et al. tested the immune system stimulation effects of dead versus live lactobacilli, concluding that live bacteria produce more TNF- $\alpha$, IL-6 and IL-10 in PBMCs than bacteria incubated with glutaraldehyde-fixed cells (Miettinen et al., 1996).

\section{Th1/Th2 alteration toward Th2: anti-inflammatory} action

On the other hand, many studies indicate that probiotics favour the production of IL-10, a cytokine produced by many cells, including Th2 cells, DCs, monocytes, B cells, keratinocytes and regulatory $T$ cells. IL-10 has an anti-inflammatory effect and primarily acts to inhibit the Th1 response (Moore et al., 2001). A study in children with atopic dermatitis found that consumption of $L$. rhamnosus GG increased IL-10 production in the serum, and that the increased production of IL-10 by PBMCs after in vitro stimulation with anti-CD3 preceded changes in serum IL-10 levels (Pessi et al., 2000).

IL-10 is a critical cytokine for the maintenance of tolerance to commensal intestinal bacteria. In its absence, mice developed severe intestinal inflammation (Kuhn et al., 1993). Administration of $L$. reuteri to IL-10deficient mice reduced the development of colitis, suggesting that probiotics exert an anti-inflammatory action in the intestine (Madsen et al., 1999). Similarly, when IL-10 knockout mice were administered with $L$. salivarius and $B$. infantis, the anti-inflammatory effects of the probiotics were thought to be caused by a reduced production of the pro-inflammatory cytokines IL-12, IFN- $\gamma$ and TNF- $\alpha$ by splenocytes and Peyer's patches cells, and not the increased TGF- $\beta$ production (McCarthy et al., 2003; O'Mahony et al., 2001). Interestingly, L. salivarius 118 can also diminish intestinal inflammation in IL-10-deficient mice by reducing the production of proinflammatory Th1 cytokines, even when bacteria are injected subcutaneously, indicating that it may not always be necessary to administer probiotics orally (Sheil et al., 2004).

It has also been proposed that $L$. reuteri and $L$. paracasei attenuate intestinal inflammation caused by Helicobacter hepaticus in IL-10-deficient mice by reducing the expression of TNF- $\alpha$ and IL-12 in the colon, which does not affect the number of pathogenic Helicobacter hepaticus present in their digestive tract (Pena et al., 2005). These studies suggest that probiotics diminish intestinal inflammation in animal models of chronic inflammatory bowel disease by 
decreasing the production of inflammatory mediators associated with an inflammatory Th1 response. In other Th1-mediated autoimmune disease models, it has been shown that probiotics can alleviate inflammatory symptoms. For example, in a murine rheumatoid arthritis model, L. casei Shirota mitigated arthritis development by reducing the Th1 response (Kato et al., 1998).

Lactobacilli also exhibited an effect in the experimental autoimmune encephalomyelitis (EAE) animal model of multiple sclerosis. However, the effect was strain-dependent. For example, $L$. reuteri aggravated $\mathrm{EAE}$, whereas $L$. casei and $L$. murines were beneficial to inducted mice (Maassen et al., 1998). To summarize, study findings using animal models suggest that the administration of probiotics can affect individuals afflicted with autoimmune disease.

However, further studies should be conducted on humans to assess whether the consumption of probiotics might aggravate autoimmune disease. The risk is that a probiotic that steers the immune system towards a Th1 inflammatory response could prove harmful to patients suffering from Th1-mediated autoimmune disease.

Although some probiotic strains seem to foster proinflammatory cytokine production, their potential use as a treatment for chronic inflammatory bowel disease would require anti-inflammatory properties. It has been demonstrated that when consumed, several strains of probiotics decreased the production of pathogenic cytokines. Thus, consumption of L. rhamnosus GG relieved symptoms of atopic dermatitis, possibly due to a reduction in the production of intestinal TNF- $\alpha$, as measured in the feces (Majamaa and Isolauri, 1997).

Mucosa samples isolated from patients with Crohn's and incubated with L. casei DN114001 or L. bulgaricus LB10 also produced substantially less TNF- $\alpha$. This phenomenon required the presence of live bacteria, however. In addition, these probiotics appeared to decrease the proportion of CD4+ T cells and TNF- $\alpha$ producing cells in the population of intraepithelial lymphocytes of the mucosa of these patients (Borruel et al., 2002).

Moreover, when intestinal mucosal extracts isolated from Crohn's patients were co-cultured with $L$. casei DN 114001 , production of IL-6 and TNF- $\alpha$ was significantly reduced (Carol et al., 2006). Nevertheless, some probiotic strains, such as the $L$. johnsonii species, were unable to decrease TNF- $\alpha$ production by macrophages upon stimulation. This again suggests a straindependent effect for probiotics used to control inflammatory reactions (Pena et al., 2004).

L. salivarius has also been shown to reduce the severity of symptoms of arthritis, using the murine collagen-induced arthritis model. This may be partly due to its capacity to reduce IL-12 and TNF- $\alpha$ and increase TGF- $\beta$ levels, as demonstrated in an experimental model of intestinal colitis (Sheil et al., 2004). In fact, the alleviation of arthritic symptoms may be explained by a decrease in IL-12 and TNF- $\alpha$, two cytokines that have been associated with this disease (Butler et al., 1999). In rats, L. rhamnosus GG treatment can also decrease arthritic inflammation (Baharav et al., 2004). However, in a clinical human trial, consumption of $L$. rhamnosus GG failed to show any beneficial effect for patients with rheumatoid arthritis (Hatakka et al., 2003).

\section{Anti-inflammatory action of probiotics via $T$ cells}

It has been suggested that probiotics can induce an anti-inflammatory action on the intestinal mucosal immune system by suppressing $T$ cell proliferation. With their highly polarized cytokine profile, $T$ cells have been known to contribute to pathological disorders such as allergies and chronic inflammatory bowel disease, under certain conditions. This capacity has been demonstrated by many probiotic strains. Indeed, $L$. rhamnosus GG, $B$. lactis, $L$. acidophilus, $L$. delbrueckii subsp. bulgaricus and Streptococcus thermophilus all suppressed the proliferation of human PBMCs, even when heat-killed. Surprisingly, a bacterial cytoplasm appeared to be responsible for inhibiting $T$ cell division, whereas the bacterial cell wall exerted no such effect on $T$ cells (Pessi et al., 1999).

Another study showed that CD4+ T cell proliferation was significantly affected when $L$. paracasei NCC2461 were incubated with CD4+ T cells during a mixed lymphocyte reaction (von der Weid et al., 2001). In addition, $T$ cells isolated from the intestinal mucosa of Crohn's patients showed decreased expression of the anti-apoptotic Bcl-2 molecule when co-incubated with $L$. casei DN 114 001, becoming more susceptible to apoptosis as a result. Results suggested that $L$. casei controls intestinal inflammation by inhibiting inflammatory $\mathrm{T}$ cell activation through its ability to sensitize $\mathrm{T}$ cells to programmed cell death (Carol et al., 2006).

These studies raise the possibility that probiotics can reduce $T$ cell activation, thus participating in their immunomodulation. The probiotic E. coli Nissle 1917 also shows the ability to reduce the proliferation of $T$ cells isolated from the blood. This probiotic acts on the $T$ cell cycle by diminishing the expression of certain proteins involved in the cell cycle progression (cyclin D2, B1 and the retinoblastoma protein). Surprisingly, this inhibition effect is observed only in T cells derived from blood, and not derived from the intestinal mucosa (Sturm et al., 2005). Although the authors argue that $E$. coli Nissle 1917 exerts an anti-inflammatory effect on the intestine by inhibiting cellular proliferation of blood derived $\mathrm{T}$ cells newly recruited in the intestine, their results indicate that the use of blood leucocytes to assess the immunomodulatory properties of probiotic strains might not be the best approach to testing intestinal immune physiology. Moreover, the majority of blood resident $T$ cells most probably do not express the combinational information that is used by adhesion molecules and chemokine receptors to penetrate intestinal tissue.

The inhibitory effect of probiotics on $\mathrm{T}$ cell proliferation could be induced by products generated as the probiotics break down intestinal content. For instance, some proteases produced by probiotics degrade cow's milk casein. Some peptides thus produced, by $L$. casei GG, among others, have antiproliferative properties on PBMC, as observed in vitro (Sutas et al., 1996b). However, many probiotic strains 
can still suppress $\mathrm{T}$ cell proliferation even after heatinactivation of their enzymatic activity (Pessi et al., 1999).

Although most probiotic strains seem to inhibit $\mathrm{T}$ cell proliferation, some strains also contribute to $T$ cell function, as noted in infection models in rodents. It has been suggested that oral administration of live $L$. casei Shirota in mice can dramatically increase cell-mediated immune response, with an enhanced delayed hypersensitivity reaction to a second exposure to the pathogenic bacterium Listeria monocytogenes (de Waard et al., 2003). Moreover, administration of $L$. casei Shirota for a prolonged period (8 weeks) prior to a first infection with $L$. monocytogenes strengthens the secondary response by improving the immunologic memory that confers protection. Further studies are needed to more precisely determine the effects of probiotics on $\mathrm{T}$ cell generation of the immune memory.

\section{Stimulation of both Th1 and Th2 response}

Although these studies demonstrate the role of probiotics in determining Th1/Th2 balance, some probiotics appear to influence both subsets. For example, it was found that administering $L$. casei, $L$. delbrueckii subsp. bulgaricus and $L$. acidophilus to mice increased systemic production of IgG1, typical of a Th1 response, and that $L$. acidophilus also enhanced the production of IgG2a, typical of a Th2 response (Perdigon et al., 2002). In addition, when L. rhamnosus HNOOI, normally considered a good inducer of IFN- $\gamma$ production, was administered orally to mice during allergen sensitization (to generate a skewed Th2 response), IL-4 and IL-5 production was enhanced (Cross et al., 2002).

Combined with the finding that $L$. rhamnosus $\mathrm{HNOOI}$ increased IL-12 and IL-18 secretion by the macrophages in vitro (Cross et al., 2002), it was concluded that $L$. rhamnosus HNOOI exercises an immunostimulatory effect on the immune system independent of the proTh1/anti-Th2 response usually associated with organisms that promote IFN- $\gamma$ production. A recent study also demonstrated that many lactobacilli and bifidobacteria strains induced IL-10 production by $\mathrm{PBMC}$, and that the monocytes were largely responsible for cytokine production in response to incubation with probiotic organisms. However, this increase in IL-10 synthesis suppressed the production of both Th1 and Th2 cytokines, indicating that probiotics may exert immunomodulatory action on both Th1 and Th2 subsets at the same time (Niers et al., 2005).

In an allergy model, it was shown that $L$. casei Shirota also decreased Th1 response (Matsuzaki et al., 1998). This contradicts the results obtained from an autoimmunity model where $L$. casei Shirota appeared to skew the Th1/Th2 balance to Th2 (Matsuzaki et al., 1997). The contradictory results obtained for the immunomodulatory properties of probiotics can be explained by the use of animal and human test models.

Table 4 summarizes the results of various studies investigating the effects of probiotic strains on Th1/Th2 balance. It is noteworthy that the strains vary widely in their capacity to influence CD4+ $T$ helper cell differentiation to the Th1 or Th2 subsets, and that many other pro- and anti-inflammatory immunomodulators act independently of this classification paradigm.

In summary, many studies have shown that each probiotic appears to influence the immune system in a particular fashion. In other words, immunomodulation properties are bacteria-specific. A future objective would be to determine exactly which components in each probiotic strain account for the differences across species in their ability to modulate the immune system. Comparative genomic analyses of the different strains could provide useful information for determining the strain-specific factors that would explain these differences. Moreover, it must be emphasized that the studies outlined in this section have examined cytokine production in response to probiotic organisms under different physiological conditions. Thus, results obtained when stimulating PBMCs with probiotics would most probably differ from those obtained when measuring local cytokine production in the intestine following oral consumption of probiotics. Consumption of probiotics results in the microbial agents interacting initially with immune cells at an intestinal induction site rather than cells found in the blood.

Table 4. Analysis of findings on the capacity of probiotic strain to alter Th1/Th2 balance

\begin{tabular}{|c|c|c|}
\hline Reference & Organism & Effect \\
\hline $\begin{array}{l}\text { (Pochard et al., } \\
\text { 2002) }\end{array}$ & L. plantarum & $\uparrow$ Th1 \\
\hline $\begin{array}{l}\text { (Pochard et al., } \\
\text { 2002) }\end{array}$ & L. lactis & $\uparrow \mathrm{Th} 1$ \\
\hline $\begin{array}{l}\text { (Pochard et al., } \\
\text { 2002) }\end{array}$ & L. casei & $\uparrow$ Th1 \\
\hline $\begin{array}{l}\text { (Pochard et al., } \\
\text { 2002) }\end{array}$ & L. rhamnosus GG & $\uparrow$ Th1 \\
\hline $\begin{array}{l}\text { (Shida et al., } \\
\text { 2002) }\end{array}$ & L. casei Shirota & $\uparrow$ Th1 \\
\hline $\begin{array}{l}\text { (Shida et al., } \\
\text { 2002) }\end{array}$ & L. johnsonii & NIL \\
\hline $\begin{array}{l}\text { (Pohjavuori et al., } \\
\text { 2004) }\end{array}$ & L. rhamnosus GG & $\uparrow$ Th1 \\
\hline $\begin{array}{l}\text { (Sutas et al., } \\
\text { 1996a) }\end{array}$ & L. rhamnosus GG & $\uparrow \mathrm{Th} 1$ \\
\hline (Sheil et al., 2004) & L. salivarius & $\downarrow$ Th1 \\
\hline $\begin{array}{l}\text { (McCarthy et al., } \\
\text { 2003) }\end{array}$ & B. infantis & $\downarrow$ Th1 \\
\hline (Pena et al., 2005) & L. reuteri & $\downarrow$ Th1 \\
\hline $\begin{array}{l}\text { (Sturm et al., } \\
2005)\end{array}$ & E. coli Nissle 1917 & $\downarrow$ Th1 \\
\hline (Kato et al., 1998) & L. casei Shirota & $\downarrow$ Th1 \\
\hline $\begin{array}{l}\text { (Perdigon et al., } \\
\text { 2002) }\end{array}$ & L. casei & $\uparrow$ Th1 \\
\hline $\begin{array}{l}\text { (Perdigon et al., } \\
\text { 2002) }\end{array}$ & $\begin{array}{l}\text { L. delbrueckii subsp. } \\
\text { bulgaricus }\end{array}$ & $\uparrow \mathrm{Th} 1$ \\
\hline $\begin{array}{l}\text { (Perdigon et al., } \\
\text { 2002) }\end{array}$ & L. acidophilus & $\begin{array}{l}\uparrow \text { Th1, } \\
\uparrow \text { Th2 }\end{array}$ \\
\hline $\begin{array}{l}\text { (Cross et al., } \\
2002)\end{array}$ & L. rhamnosus HNOOI & $\begin{array}{l}\text { 个 Th1, } \\
\text { Th2 }\end{array}$ \\
\hline
\end{tabular}

7. In vitro analysis of cytokines production induced by probiotics

In vitro studies refer to studies in which isolated cells are exposed directly, in culture, to probiotics cells. In vitro systems frequently are highly unphysiocolgical in nature when they use cells in isolation from other components with which they would normally interact. It is why models that mimic the mucosa should be preferred to blood cell models whenever possible when evaluating 
probiotic immune function. Even if evaluation of the stimulation of blood cell immune response by probiotics is practical to implement, it does not represent the physiological reality, and an examination of intestinal cell immune response would be the best option. For each new probiotic strain, profiles of the cytokines secreted by lymphocytes, enterocytes and/or DCs that come into contact with the strain should be established. This would allow certification of the pro- and anti-inflammatory properties of the strain in question and would define specific clinical uses. Probiotic products purporting to be immune boosters should be supported by accurate data substantiating the claim of each strain proposed.

Extrapolations from in vitro studies to the whole body context should only be made cautiously and probiotic effects observed in vitro should be backed up by properly conducted clinical studies (i.e., randomized double blind). More detailed studies are needed to determine the precise action modes of probiotics on both mucosal and systemic immunity. The use of transgenic or knockout mice and other animal models would allow a better understanding of these mechanisms. Further research funding would encourage specialized laboratories to enter the field of probiotics.

\section{Clinical trials in humans}

The impact of probiotics on the Th1/Th2 balance has led to many clinical trials to evaluate the effects of probiotics in the treatment of several chronic inflammatory diseases and allergies.

\section{Atopic diseases}

The rise in prevalence of atopic diseases in industrial societies cannot be explained by genetic factors of by novel emerging allergens only. This phenomenon could be related to reduce exposure to microbes at an early age. Indeed, the gut microbiota initial development is considered a key determinant in the development of normal gut barrier function and healthy host. The healthy gastrointestinal microbiota promotes the Th1 balance and is possibly associated with two structural components of bacteria (PAMPs): LPS (lipopolysaccharide) and CpG motif (a 6 base DNA motif consisting of an unmethylated dinucleotide). LPS portion of Gram-negative bacteria (endotoxin) binds to TLR4 on the cell surface, whereas, the CpG motif must be taken up into the cell by endocytosis. Non pathogenic microbes have a direct anti-inflammatory effect via the inhibition of NF $\kappa \beta$ transcription factor (Sudo et al., 1997).

In a double-blind clinical trial testing the effect of probiotics for the prevention of atopic diseases, $L$. rhamnosus GG was administered to pregnant women whose unborn children were at high risk for being atopic (genetically), lactating mothers and children under six months old. Results showed that atopic eczema prevalence in children was reduced to up to four years of age (Kalliomaki et al., 2001; Kalliomaki et al., 2003).

The consumption of probiotics also alleviated clinical symptoms in children suffering from atopic dermatitis (Isolauri et al., 2000; Rosenfeldt et al., 2003), and some data point to a beneficial effect in children who are allergic to cow's milk (Majamaa and Isolauri, 1997).
However, no improvement in symptoms was noted following consumption of Lactobacillus GG in adults allergic to birch pollen (Helin et al., 2002). Another study (Taylor et al., 2007) tested supplementation with $L$. acidophilus in high-risk infants for atopic dermatitis (born from atopic women). A total of 178 infants were treated with placebo or $L$. acidophilus from birth to 6 months. This study showed that $L$. acidophilus did not reduce the risk of atopic dermatitis and was even associated with increased allergen sensitization. Kukkonen et al. (2007) examined the effects of probiotics and prebiotics combination on allergy prevention in a larger population of allergy-prone infants than previously. They randomized 1223 pregnant women to receive either placebo or daily probiotic supplements containing four probiotic strains - L. rhamnosus GG; L. rhamnosus LC705; B. breve Bb99; and Propionibacterium freudenreichii ssp. shermanii JS for the two to four weeks prior to delivery. The newborns were then supplemented with either the same probiotics in combination with galacto-oligosaccharides (461 babies) or placebo (464 babies) for six months. At 2 years, they evaluated the cumulative incidence of allergic diseases (food allergy, eczema, asthma, and allergic rhinitis) and IgE sensitization. While no significant difference between the supplemented and placebo groups were observed for allergic disease overall, Kukkonen et al. (2007) reported that supplementation with the probiotic, prebiotic mixture was associated with a 26 per cent reduction in eczema, while atopic eczema was reduced by 34 per cent. The results suggest an inverse association between atopic diseases and colonization of the gut by probiotics (Kukkonen et al., 2007).

These studies suggest that probiotics can be useful in the treatment and prevention of allergies when administered in infancy, but less useful for adults. Thus, no protective effect was observed for other atopic symptoms in adults such as food allergies or asthma. Further clinical studies would be needed to determine the efficacy of probiotics in the prevention of atopic diseases.

\section{Chronic inflammatory bowel diseases}

Inflammation is frequently accompanied by imbalance in the intestinal microbiota. Healthy individuals are tolerant to their own microbiota while this tolerance is abrogated in patients with inflammatory bowel disease (Duchmann et al., 1995). An increasing number of clinical and experimental studies demonstrate the importance of the resident microbiota within the intestinal lumen in driving the inflammatory responses in Crohn's disease and ulcerative colitis. For example, transgenic mice with deletion of the TCR spontaneously develop colitis in response to the gut microbiota. If organised GALT is removed from the mice by appendectomy at neonatal age, tolerance to gut microbiota without colitis develops, indicating that the initial colonization pattern determines subsequent immunological processes. With respect to probiotic treatments for chronic inflammatory bowel diseases, results so far have been disappointing. In the rare cases where a clinical effect was observed, the beneficial effect of the probiotic consumption was not necessarily an improvement over the use of previously prescribed drugs. 


\section{Crohn's disease}

Reduction in disease activity has been achieved in paediatric patients with Crohn's disease by probiotic intervention (Gupta et al., 2000). In adults operated for the condition, however, a probiotic preparation failed to reduce the risk of endoscopic recurrence during oneyear follow-up. L. rhamnosus GG seemed unable to prevent the recurrence or lessen the severity of lesions following colon resection in Crohn's patients (Prantera et al., 2002; Schultz et al., 2004). On the other hand, the yeast Saccharomyces boulardii, when administered in combination with mesalamine, reduced the number of relapses in patients suffering from Crohn's disease (Guslandi et al., 2000).

\section{Ulcerative colitis}

Fermented milk containing bifidobacteria, when combined with sulfasalazine or 5ASA, appears to be somewhat beneficial for patients suffering from mildly to moderately severe ulcerative colitis. This effect has been associated with the increased production of short chain fatty acids in the feces (Kato et al., 2004). A recent, encouraging study suggested that the probiotic preparation VSL \#3 contributes to remission in patients suffering from ulcerative colitis, but only in patients with mild to moderate symptoms who did not respond to conventional treatment (Bibiloni et al., 2005). Meanwhile, the best evidence that probiotics are useful in the treatment of inflammatory bowel diseases arises from studies that have demonstrated a beneficial clinical outcome for VSL \#3 in the prevention of pouchitis following antibiotic-induced remission (Gionchetti et al., 2003; Gionchetti et al., 2000; Mimura et al., 2004). Moreover, L. rhamnosus GG by itself also appeared to reduce episodes of pouchitis from about $30 \%$ to $7 \%$ over a three-year period by delaying onset of the first clinical episode (Gosselink et al., 2004). E. coli Nissle 1917 appeared to have a clinical impact similar to that obtained by the drug mesalazine (Kruis et al., 2004; Kruis et al., 1997; Rembacken et al., 1999).

In summary, although a particularly significant clinical effect of the use of probiotics remains to be clearly established, with the exception of the treatment of pouchitis, bacteriotherapy and the use of probiotics remains a major research focus in the treatment of intestinal disorders aiming to re-establish homeostasis of the intestinal microbiota (Borody et al., 2004).

\section{References}

Amrouche, T., Boutin, Y., Prioult, G., Fliss, I. (2006). Effects of bifidobacterial cytoplasm, cell wall and exopolysaccharide on mouse lymphocyte proliferation and cytokine production. Inter Dairy J 16, 70-80.

Arunachalam, K., Gill, H.S., and Chandra, R.K. (2000). Enhancement of natural immune function by dietary consumption of Bifidobacterium lactis (HN019). Eur J Clin Nutr 54, 263-267.

Baharav, E., Mor, F., Halpern, M., and Weinberger, A. (2004). Lactobacillus GG bacteria ameliorate arthritis in Lewis rats. J Nutr 134, 1964-1969.

Bettelli, E., Carrier, Y., Gao, W., Korn, T., Strom, T.B., Oukka, M., Weiner, H.L., and Kuchroo, V.K. (2006). Reciprocal developmental pathways for the generation

\section{Conclusion}

The intestinal microbiota acts as primary agent in the development of the postnatal immune system such as oral tolerance and immunity. The interaction of probiotics and enterocytes is key to the initiation of immunomodulation.

Probiotics act on a wide variety of cells in the intestine to modulate the immune system towards a proor anti-inflammatory action, depending on strain, setting and immunological parameters measured, and the type of cells being acted upon.

Models that mimic the mucosa should be preferred whenever possible when evaluating probiotic immune function. Albeit more practical to implement, evaluation of the stimulation of blood cell immune response by probiotics does not represent the physiological reality, and an examination of intestinal cell immune response would be the better option. For each new probiotic strain, profiles of the cytokines secreted by lymphocytes, enterocytes and/or DCs that come into contact with the strain should be established. This would allow certification of the pro- and anti-inflammatory properties of the strain in question and would define specific clinical uses. Probiotic products purporting to be immune boosters should be supported by accurate data substantiating the claim of each strain proposed. Probiotic effects observed in vitro should be backed up by properly conducted clinical studies (such as randomized double blind trials).

However, these observations do not explain how these organisms might induce these effects, nor do they explain which bacterial molecules or cellular receptors are responsible for them. More detailed studies are needed to determine the precise action modes of probiotics on both mucosal and systemic immunity. The use of transgenic or knockout mice and other animal models would allow a better understanding of these mechanisms. Further research funding would encourage specialized laboratories to enter the field of probiotics.

\section{Acknowledgements}

We thank Natural Health Products Directorate (NHPD), Health Products and Food Branch of Health Canada for the financial support of this project. We thank the administrative staff of INAF and of University Laval. Thanks also to Margaret McKyes for checking the English.

of pathogenic effector $\mathrm{TH} 17$ and regulatory $\mathrm{T}$ cells. Nature 441, 235-238.

Bibiloni, R., Fedorak, R.N., Tannock, G.W., Madsen, K.L., Gionchetti, P., Campieri, M., De Simone, C., and Sartor, R.B. (2005). VSL\#3 probiotic-mixture induces remission in patients with active ulcerative colitis. Am J Gastroenterol 100, 1539-1546.

Borody, T.J., Warren, E.F., Leis, S.M., Surace, R., Ashman, O., and Siarakas, S. (2004). Bacteriotherapy using fecal flora: toying with human motions. J Clin Gastroenterol 38, 475-483.

Borruel, N., Carol, M., Casellas, F., Antolin, M., de Lara, F., Espin, E., Naval, J., Guarner, F., and Malagelada, J.R. (2002). Increased mucosal tumour necrosis factor alpha production in Crohn's disease can 
be downregulated ex vivo by probiotic bacteria. Gut 51, 659-664.

Braat, H., van den Brande, J., van Tol, E., Hommes, D., Peppelenbosch, M., and van Deventer, S. (2004). Lactobacillus rhamnosus induces peripheral hyporesponsiveness in stimulated CD4+ $\mathrm{T}$ cells via modulation of dendritic cell function. Am J Clin Nutr 80, 1618-1625.

Butler, D.M., Malfait, A.M., Maini, R.N., Brennan, F.M., and Feldmann, M. (1999). Anti-IL-12 and anti-TNF antibodies synergistically suppress the progression of murine collagen-induced arthritis. Eur J Immunol 29, 2205-2212.

Carol, M., Borruel, N., Antolin, M., Llopis, M., Casellas, F., Guarner, F., and Malagelada, J.R. (2006). Modulation of apoptosis in intestinal lymphocytes by a probiotic bacteria in Crohn's disease. J Leukoc Biol 79, 917-922.

Chen, Y., Kuchroo, V.K., Inobe, J., Hafler, D.A., and Weiner, H.L. (1994). Regulatory T cell clones induced by oral tolerance: suppression of autoimmune encephalomyelitis. Science 265, 1237-1240.

Christensen, H.R., Frokiaer, H., and Pestka, J.J. (2002). Lactobacilli differentially modulate expression of cytokines and maturation surface markers in murine dendritic cells. J Immunol 168, 171-178.

Claassen, E., Van Winsen, R., Posno, M., and Boersma, W.J. (1995). New and safe "oral" live vaccines based on lactobacillus. Adv Exp Med Biol 371B, 15531558.

Cross, M.L., Mortensen, R.R., Kudsk, J., and Gill, H.S. (2002). Dietary intake of Lactobacillus rhamnosus HNOO1 enhances production of both Th1 and Th2 cytokines in antigen-primed mice. Med Microbiol Immunol 191, 49-53.

Cummings, J.H., Antoine, J.M., Azpiroz, F., BourdetSicard, R., Brandtzaeg, P., Calder, P.C., Gibson, G.R., Guarner, F., Isolauri, E., Pannemans, D., et al. (2004). PASSCLAIM--gut health and immunity. Eur J Nutr 43 Suppl 2, II118-II173.

de Waard, R., Claassen, E., Bokken, G.C., Buiting, B., Garssen, J., and Vos, J.G. (2003). Enhanced immunological memory responses to Listeria monocytogenes in rodents, as measured by delayedtype hypersensitivity (DTH), adoptive transfer of DTH, and protective immunity, following Lactobacillus casei Shirota ingestion. Clin Diagn Lab Immunol 10, 59-65.

Delneste, Y., Donnet-Hughes, A., and Schiffrin, E.J. (1998). Functional foods: mechanisms of action on immunocompetent cells. Nutr Rev 56, S93-98.

Delves, P.J., and Roitt, I.M. (2000). The immune system. First of two parts. N Engl J Med 343, 37-49.

Di Giacinto, C., Marinaro, M., Sanchez, M., Strober, W., and Boirivant, M. (2005). Probiotics ameliorate recurrent Th1-mediated murine colitis by inducing IL-10 and IL-10-dependent TGF-beta-bearing regulatory cells. $\mathrm{J}$ Immunol 174, 3237-3246.

Donnet-Hughes, A., Rochat, F., Serrant, P., Aeschlimann, J.M., and Schiffrin, E.J. (1999). Modulation of nonspecific mechanisms of defense by lactic acid bacteria: effective dose. J Dairy Sci $82,863-869$.

Drakes, M., Blanchard, T., and Czinn, S. (2004). Bacterial probiotic modulation of dendritic cells. Infect Immun 72, 3299-3309.

Duchmann, R., Kaiser, I., Hermann, E., Mayet, W., Ewe, K., and Meyer zum Buschenfelde, K.H. (1995). Tolerance exists towards resident intestinal flora but is broken in active inflammatory bowel disease (IBD). Clin Exp Immunol 102, 448-455.

Fukushima, Y., Kawata, Y., Hara, H., Terada, A., and Mitsuoka, T. (1998). Effect of a probiotic formula on intestinal immunoglobulin A production in healthy children. Int J Food Microbiol 42, 39-44.

Galdeano, C.M., and Perdigon, G. (2004). Role of viability of probiotic strains in their persistence in the gut and in mucosal immune stimulation. J Appl Microbiol 97, 673-681.

Gill, H.S., Rutherfurd, K.J., and Cross, M.L. (2001a). Dietary probiotic supplementation enhances natural killer cell activity in the elderly: an investigation of age-related immunological changes. J Clin Immunol 21, 264-271.

Gill, H.S., Rutherfurd, K.J., Cross, M.L., and Gopal, P.K. (2001b). Enhancement of immunity in the elderly by dietary supplementation with the probiotic Bifidobacterium lactis HN019. Am J Clin Nutr 74, 833839.

Gionchetti, P., Rizzello, F., Helwig, U., Venturi, A., Lammers, K.M., Brigidi, P., Vitali, B., Poggioli, G., Miglioli, M., and Campieri, M. (2003). Prophylaxis of pouchitis onset with probiotic therapy: a double-blind, placebo-controlled trial. Gastroenterology 124, 12021209.

Gionchetti, P., Rizzello, F., Venturi, A., Brigidi, P., Matteuzzi, D., Bazzocchi, G., Poggioli, G., Miglioli, M., and Campieri, M. (2000). Oral bacteriotherapy as maintenance treatment in patients with chronic pouchitis: a double-blind, placebo-controlled trial. Gastroenterology 119, 305-309.

Gosselink, M.P., Schouten, W.R., van Lieshout, L.M., Hop, W.C., Laman, J.D., and Ruseler-van Embden, J.G. (2004). Delay of the first onset of pouchitis by oral intake of the probiotic strain Lactobacillus rhamnosus GG. Dis Colon Rectum 47, 876-884.

Groux, H., O'Garra, A., Bigler, M., Rouleau, M., Antonenko, S., de Vries, J.E., and Roncarolo, M.G. (1997). A CD4+ T-cell subset inhibits antigen-specific Tcell responses and prevents colitis. Nature 389, 737742.

Gupta, P., Andrew, H., Kirschner, B.S., and Guandalini, S. (2000). Is lactobacillus GG helpful in children with Crohn's disease? Results of a preliminary, open-label study. J Pediatr Gastroenterol Nutr 31, 453457.

Guslandi, M., Mezzi, G., Sorghi, M., and Testoni, P.A. (2000). Saccharomyces boulardii in maintenance treatment of Crohn's disease. Dig Dis Sci 45, 14621464.

Haller, D., Bode, C., Hammes, W.P., Pfeifer, A.M., Schiffrin, E.J., and Blum, S. (2000). Non-pathogenic bacteria elicit a differential cytokine response by intestinal epithelial cell/leucocyte co-cultures. Gut 47, 7987.

Harrington, L.E., Mangan, P.R., and Weaver, C.T. (2006). Expanding the effector CD4 T-cell repertoire: the Th17 lineage. Curr Opin Immunol 18, 349-356.

Hart, A.L., Lammers, K., Brigidi, P., Vitali, B., Rizzello, F., Gionchetti, P., Campieri, M., Kamm, M.A., Knight, S.C., and Stagg, A.J. (2004). Modulation of human dendritic cell phenotype and function by probiotic bacteria. Gut 53, 1602-1609.

Hatakka, K., Martio, J., Korpela, M., Herranen, M., Poussa, T., Laasanen, T., Saxelin, M., Vapaatalo, H., Moilanen, E., and Korpela, R. (2003). Effects of probiotic 
therapy on the activity and activation of mild rheumatoid arthritis--a pilot study. Scand J Rheumatol 32, 211-215.

Helin, T., Haahtela, S., and Haahtela, T. (2002). No effect of oral treatment with an intestinal bacterial strain, Lactobacillus rhamnosus (ATCC 53103), on birch-pollen allergy: a placebo-controlled double-blind study. Allergy 57, 243-246.

Ibnou-Zekri, N., Blum, S., Schiffrin, E.J., and von der Weid, T. (2003). Divergent patterns of colonization and immune response elicited from two intestinal Lactobacillus strains that display similar properties in vitro. Infect Immun 71, 428-436.

Isolauri, E., Arvola, T., Sutas, Y., Moilanen, E., and Salminen, S. (2000). Probiotics in the management of atopic eczema. Clin Exp Allergy 30, 1604-1610.

Isolauri, E., Joensuu, J., Suomalainen, H., Luomala, M., and Vesikari, T. (1995). Improved immunogenicity of oral $D \times$ RRV reassortant rotavirus vaccine by Lactobacillus casei GG. Vaccine 13, 310-312.

Kaila, M., Isolauri, E., Saxelin, M., Arvilommi, H., and Vesikari, T. (1995). Viable versus inactivated Lactobacillus strain GG in acute rotavirus diarrhoea. Arch Dis Child 72, 51-53.

Kalliomaki, M., Salminen, S., Arvilommi, H., Kero, P., Koskinen, P., and Isolauri, E. (2001). Probiotics in primary prevention of atopic disease: a randomised placebo-controlled trial. Lancet 357, 1076-1079.

Kalliomaki, M., Salminen, S., Poussa, T., Arvilommi, H., and Isolauri, E. (2003). Probiotics and prevention of atopic disease: 4-year follow-up of a randomised placebo-controlled trial. Lancet 361, 1869-1871.

Kato, I., Endo-Tanaka, K., and Yokokura, T. (1998). Suppressive effects of the oral administration of Lactobacillus casei on type II collagen-induced arthritis in DBA/1 mice. Life Sci 63, 635-644.

Kato, K., Mizuno, S., Umesaki, Y., Ishii, Y., Sugitani, M., Imaoka, A., Otsuka, M., Hasunuma, O., Kurihara, R., Iwasaki, A., et al. (2004). Randomized placebocontrolled trial assessing the effect of bifidobacteriafermented milk on active ulcerative colitis. Aliment Pharmacol Ther 20, 1133-1141.

Kishi, A., Uno, K., Matsubara, Y., Okuda, C., and Kishida, T. (1996). Effect of the oral administration of Lactobacillus brevis subsp. coagulans on interferonalpha producing capacity in humans. J Am Coll Nutr 15, 408-412.

Korzenik, J.R., and Podolsky, D.K. (2006). Evolving knowledge and therapy of inflammatory bowel disease. Nat Rev Drug Discov 5, 197-209.

Kruis, W., Fric, P., Pokrotnieks, J., Lukas, M., Fixa, B., Kascak, M., Kamm, M.A., Weismueller, J., Beglinger, C., Stolte, M., et al. (2004). Maintaining remission of ulcerative colitis with the probiotic Escherichia coli Nissle 1917 is as effective as with standard mesalazine. Gut 53, 1617-1623.

Kruis, W., Schutz, E., Fric, P., Fixa, B., Judmaier, G., and Stolte, M. (1997). Double-blind comparison of an oral Escherichia coli preparation and mesalazine in maintaining remission of ulcerative colitis. Aliment Pharmacol Ther 11, 853-858.

Kuhn, R., Lohler, J., Rennick, D., Rajewsky, K., and Muller, W. (1993). Interleukin-10-deficient mice develop chronic enterocolitis. Cell 75, 263-274.

Kukkonen, K., Savilahti, E., Haahtela, T., JuntunenBackman, K., Korpela, R., Poussa, T., Tuure, T., and Kuitunen, M. (2007). Probiotics and prebiotic galactooligosaccharides in the prevention of allergic diseases: a randomized, double-blind, placebo-controlled trial. J Allergy Clin Immunol 119, 192-198.

Lammers, K.M., Helwig, U., Swennen, E., Rizzello, F., Venturi, A., Caramelli, E., Kamm, M.A., Brigidi, P., Gionchetti, P., and Campieri, M. (2002). Effect of probiotic strains on interleukin 8 production by HT29/19A cells. Am J Gastroenterol 97, 1182-1186.

Leblanc, J., Fliss, I., and Matar, C. (2004). Induction of a humoral immune response following an Escherichia coli 0157:H7 infection with an immunomodulatory peptidic fraction derived from Lactobacillus helveticusfermented milk. Clin Diagn Lab Immunol 11, 1171-1181.

Lefrancois, L., and Puddington, L. (2006). Intestinal and pulmonary mucosal $\mathrm{T}$ cells: local heroes fight to maintain the status quo. Annu Rev Immunol 24, 681704.

Leonard, W.J. (2003). Type I cytokines and interferons and their receptors. In Fundamental Immunology (W. E. Paul, ed) Lippincott Williams \& Wilkins, Philadelphia 701-747.

Link-Amster, H., Rochat, F., Saudan, K.Y., Mignot, O., and Aeschlimann, J.M. (1994). Modulation of a specific humoral immune response and changes in intestinal flora mediated through fermented milk intake. FEMS Immunol Med Microbiol 10, 55-63.

Ma, D., Forsythe, P., and Bienenstock, J. (2004). Live Lactobacillus reuteri is essential for the inhibitory effect on tumor necrosis factor alpha-induced interleukin-8 expression. Infect Immun 72, 5308-5314.

Maassen, C.B., van Holten, J.C., Balk, F., Heijne den Bak-Glashouwer, M.J., Leer, R., Laman, J.D., Boersma, W.J., and Claassen, E. (1998). Orally administered Lactobacillus strains differentially affect the direction and efficacy of the immune response. Vet Q 20 Suppl 3, S81-83.

Maassen, C.B., van Holten-Neelen, C., Balk, F., den Bak-Glashouwer, M.J., Leer, R.J., Laman, J.D., Boersma, W.J., and Claassen, E. (2000). Straindependent induction of cytokine profiles in the gut by orally administered Lactobacillus strains. Vaccine 18, 2613-2623.

Macdonald, T.T., and Monteleone, G. (2005). Immunity, inflammation, and allergy in the gut. Science 307, 1920-1925.

MacDonald, T.T., Monteleone, G., and Pender, S.L. (2000). Recent developments in the immunology of inflammatory bowel disease. Scand J Immunol 51, 2-9.

Madsen, K.L., Doyle, J.S., Jewell, L.D., Tavernini, M.M., and Fedorak, R.N. (1999). Lactobacillus species prevents colitis in interleukin 10 gene-deficient mice. Gastroenterology 116, 1107-1114.

Majamaa, H., and Isolauri, E. (1997). Probiotics: a novel approach in the management of food allergy. $J$ Allergy Clin Immunol 99, 179-185.

Majamaa, H., Isolauri, E., Saxelin, M., and Vesikari, T. (1995). Lactic acid bacteria in the treatment of acute rotavirus gastroenteritis. J Pediatr Gastroenterol Nutr 20, 333-338.

Matsuzaki, T., Nagata, Y., Kado, S., Uchida, K., Kato, I., Hashimoto, S., and Yokokura, T. (1997). Prevention of onset in an insulin-dependent diabetes mellitus model, NOD mice, by oral feeding of Lactobacillus casei. Apmis 105, 643-649.

Matsuzaki, T., Yamazaki, R., Hashimoto, S., and Yokokura, T. (1998). The effect of oral feeding of Lactobacillus casei strain Shirota on immunoglobulin $\mathrm{E}$ production in mice. J Dairy Sci 81, 48-53. 
McCarthy, J., O'Mahony, L., O'Callaghan, L., Sheil, B., Vaughan, E.E., Fitzsimons, N., Fitzgibbon, J., O'Sullivan, G.C., Kiely, B., Collins, J.K., et al. (2003). Double blind, placebo controlled trial of two probiotic strains in interleukin 10 knockout mice and mechanistic link with cytokine balance. Gut 52, 975-980.

McCracken, V.J., Chun, T., Baldeon, M.E., Ahrne, S., Molin, G., Mackie, R.I., and Gaskins, H.R. (2002). TNFalpha sensitizes HT-29 colonic epithelial cells to intestinal lactobacilli. Exp Biol Med (Maywood) 227, 665670.

Mestecky, J., Blumberg, R.S., Kiyono, H., McGhee, J.R. (2003). The mucosal immune system. In Fundamental Immunology (W. E. Paul, ed) Lippincott Williams \& Wilkins, Philadelphia 965-1021.

Miettinen, M., Matikainen, S., Vuopio-Varkila, J., Pirhonen, J., Varkila, K., Kurimoto, M., and Julkunen, I. (1998). Lactobacilli and streptococci induce interleukin12 (IL-12), IL-18, and gamma interferon production in human peripheral blood mononuclear cells. Infect Immun 66, 6058-6062.

Miettinen, M., Vuopio-Varkila, J., and Varkila, K. (1996). Production of human tumor necrosis factor alpha, interleukin-6, and interleukin-10 is induced by lactic acid bacteria. Infect Immun 64, 5403-5405.

Mimura, T., Rizzello, F., Helwig, U., Poggioli, G., Schreiber, S., Talbot, I.C., Nicholls, R.J., Gionchetti, P., Campieri, M., and Kamm, M.A. (2004). Once daily high dose probiotic therapy (VSL\#3) for maintaining remission in recurrent or refractory pouchitis. Gut 53, 108-114.

Mohamadzadeh, M., Olson, S., Kalina, W.V., Ruthel, G., Demmin, G.L., Warfield, K.L., Bavari, S., and Klaenhammer, T.R. (2005). Lactobacilli activate human dendritic cells that skew $\mathrm{T}$ cells toward $\mathrm{T}$ helper 1 polarization. Proc Natl Acad Sci U S A 102, 2880-2885.

Moore, K.W., de Waal Malefyt, R., Coffman, R.L., and O'Garra, A. (2001). Interleukin-10 and the interleukin-10 receptor. Annu Rev Immunol 19, 683-765.

Moser, M. (2003). Dendritic cells. In Fundamental Immunology (W. E. Paul, ed) Lippincott Williams \& Wilkins, Philadelphia 455-480.

Mowat, A.M. (2003). Anatomical basis of tolerance and immunity to intestinal antigens. Nat Rev Immunol 3, 331-341.

Murphy, K.M., and Reiner, S.L. (2002). The lineage decisions of helper T cells. Nat Rev Immunol 2, 933-944.

Muscettola, M., Massai, L., Tanganelli, C., and Grasso, G. (1994). Effects of lactobacilli on interferon production in young and aged mice. Ann N Y Acad Sci 717, 226-232.

Niers, L.E., Timmerman, H.M., Rijkers, G.T., van Bleek, G.M., van Uden, N.O., Knol, E.F., Kapsenberg, M.L., Kimpen, J.L., and Hoekstra, M.O. (2005). Identification of strong interleukin-10 inducing lactic acid bacteria which down-regulate $\mathrm{T}$ helper type 2 cytokines. Clin Exp Allergy 35, 1481-1489.

O'Mahony, L., Feeney, M., O'Halloran, S., Murphy, L., Kiely, B., Fitzgibbon, J., Lee, G., O'Sullivan, G., Shanahan, F., and Collins, J.K. (2001). Probiotic impact on microbial flora, inflammation and tumour development in IL-10 knockout mice. Aliment Pharmacol Ther 15, 1219-1225.

Ogawa, T., Asai, Y., Tamai, R., Makimura, Y., Sakamoto, H., Hashikawa, S., and Yasuda, K. (2006). Natural killer cell activities of synbiotic Lactobacillus casei ssp. casei in conjunction with dextran. Clin Exp Immunol 143, 103-109.
Olivares, M., Diaz-Ropero, M.P., Sierra, S., LaraVilloslada, F., Fonolla, J., Navas, M., Rodriguez, J.M., and Xaus, J. (2007). Oral intake of Lactobacillus fermentum CECT5716 enhances the effects of influenza vaccination. Nutrition 23, 254-260.

Otte, J.M., and Podolsky, D.K. (2004). Functional modulation of enterocytes by gram-positive and gramnegative microorganisms. Am J Physiol Gastrointest Liver Physiol 286, G613-626.

Park, J.H., Um, J.I., Lee, B.J., Goh, J.S., Park, S.Y., Kim, W.S., and Kim, P.H. (2002). Encapsulated Bifidobacterium bifidum potentiates intestinal IgA production. Cell Immunol 219, 22-27.

Pelto, L., Isolauri, E., Lilius, E.M., Nuutila, J., and Salminen, S. (1998). Probiotic bacteria down-regulate the milk-induced inflammatory response in milkhypersensitive subjects but have an immunostimulatory effect in healthy subjects. Clin Exp Allergy 28, 14741479.

Pena, J.A., Li, S.Y., Wilson, P.H., Thibodeau, S.A., Szary, A.J., and Versalovic, J. (2004). Genotypic and phenotypic studies of murine intestinal lactobacilli: species differences in mice with and without colitis. Appl Environ Microbiol 70, 558-568.

Pena, J.A., Rogers, A.B., Ge, Z., Ng, V., Li, S.Y., Fox, J.G., and Versalovic, J. (2005). Probiotic Lactobacillus spp. diminish Helicobacter hepaticus-induced inflammatory bowel disease in interleukin-10-deficient mice. Infect Immun 73, 912-920.

Perdigon, G., de Macias, M.E., Alvarez, S., Oliver, G., and de Ruiz Holgado, A.P. (1988). Systemic augmentation of the immune response in mice by feeding fermented milks with Lactobacillus casei and Lactobacillus acidophilus. Immunology 63, 17-23.

Perdigon, G., Maldonado Galdeano, C., Valdez, J.C., and Medici, M. (2002). Interaction of lactic acid bacteria with the gut immune system. Eur J Clin Nutr 56 Suppl 4, S21-26.

Pessi, T., Sutas, Y., Hurme, M., and Isolauri, E. (2000). Interleukin-10 generation in atopic children following oral Lactobacillus rhamnosus GG. Clin Exp Allergy 30, 1804-1808.

Pessi, T., Sutas, Y., Saxelin, M., Kallioinen, H., and Isolauri, E. (1999). Antiproliferative effects of homogenates derived from five strains of candidate probiotic bacteria. Appl Environ Microbiol 65, 4725-4728.

Pochard, P., Gosset, P., Grangette, C., Andre, C., Tonnel, A.B., Pestel, J., and Mercenier, A. (2002). Lactic acid bacteria inhibit $\mathrm{TH} 2$ cytokine production by mononuclear cells from allergic patients. J Allergy Clin Immunol 110, 617-623.

Pohjavuori, E., Viljanen, M., Korpela, R., Kuitunen, M., Tiittanen, M., Vaarala, O., and Savilahti, E. (2004). Lactobacillus GG effect in increasing IFN-gamma production in infants with cow's milk allergy. J Allergy Clin Immunol 114, 131-136.

Prantera, C., Scribano, M.L., Falasco, G., Andreoli, A., and Luzi, C. (2002). Ineffectiveness of probiotics in preventing recurrence after curative resection for Crohn's disease: a randomised controlled trial with Lactobacillus GG. Gut 51, 405-409.

Prioult, G., Fliss, I., and Pecquet, S. (2003). Effect of probiotic bacteria on induction and maintenance of oral tolerance to beta-lactoglobulin in gnotobiotic mice. Clin Diagn Lab Immunol 10, 787-792.

Prioult, G., Pecquet, S., and Fliss, I. (2004). Stimulation of interleukin-10 production by acidic beta- 
lactoglobulin-derived peptides hydrolyzed with Lactobacillus paracasei NCC2461 peptidases. Clin Diagn Lab Immunol 11, 266-271.

Rembacken, B.J., Snelling, A.M., Hawkey, P.M., Chalmers, D.M., and Axon, A.T. (1999). Non-pathogenic Escherichia coli versus mesalazine for the treatment of ulcerative colitis: a randomised trial. Lancet $354,635-$ 639.

Rigby, R.J., Knight, S.C., Kamm, M.A., and Stagg, A.J. (2005). Production of interleukin (IL)-10 and IL-12 by murine colonic dendritic cells in response to microbial stimuli. Clin Exp Immunol 139, 245-256.

Rosenfeldt, V., Benfeldt, E., Nielsen, S.D., Michaelsen, K.F., Jeppesen, D.L., Valerius, N.H., and Paerregaard, A. (2003). Effect of probiotic Lactobacillus strains in children with atopic dermatitis. J Allergy Clin Immunol 111, 389-395.

Ruiz, P.A., Hoffmann, M., Szcesny, S., Blaut, M., and Haller, D. (2005). Innate mechanisms for Bifidobacterium lactis to activate transient pro-inflammatory host responses in intestinal epithelial cells after the colonization of germ-free rats. Immunology 115, 441450.

Schiffrin, E.J. (1994). Immunomodulation of human blood cells following the ingestion of lactic acid bacteria. J Dairy Sci 78, 491-497.

Schiffrin, E.J., Brassart, D., Servin, A.L., Rochat, F., and Donnet-Hughes, A. (1997). Immune modulation of blood leukocytes in humans by lactic acid bacteria: criteria for strain selection. Am J Clin Nutr 66, 515S520 S.

Schultz, M., Timmer, A., Herfarth, H.H., Sartor, R.B., Vanderhoof, J.A., and Rath, H.C. (2004). Lactobacillus GG in inducing and maintaining remission of Crohn's disease. BMC Gastroenterol 4, 5.

Sheih, Y.H., Chiang, B.L., Wang, L.H., Liao, C.K., and Gill, H.S. (2001). Systemic immunity-enhancing effects in healthy subjects following dietary consumption of the lactic acid bacterium Lactobacillus rhamnosus HN001. J Am Coll Nutr 20, 149-156.

Sheil, B., McCarthy, J., O'Mahony, L., Bennett, M.W., Ryan, P., Fitzgibbon, J.J., Kiely, B., Collins, J.K., and Shanahan, F. (2004). Is the mucosal route of administration essential for probiotic function? Subcutaneous administration is associated with attenuation of murine colitis and arthritis. Gut 53, 694700.

Shevach, E.M. (2000). Suppressor T cells: Rebirth, function and homeostasis. Curr Biol 10, R572-575.

Shida, K., Kiyoshima-Shibata, J., Nagaoka, M., Watanabe, K., and Nanno, M. (2006). Induction of interleukin-12 by lactobacillus strains having a rigid cell wall resistant to intracellular digestion. J Dairy Sci 89, 3306-3317.

Shida, K., Takahashi, R., Iwadate, E., Takamizawa, K., Yasui, H., Sato, T., Habu, S., Hachimura, S., and Kaminogawa, S. (2002). Lactobacillus casei strain Shirota suppresses serum immunoglobulin $E$ and immunoglobulin $\mathrm{G} 1$ responses and systemic anaphylaxis in a food allergy model. Clin Exp Allergy 32, 563-570.

Smits, H.H., Engering, A., van der Kleij, D., de Jong, E.C., Schipper, K., van Capel, T.M., Zaat, B.A., Yazdanbakhsh, M., Wierenga, E.A., van Kooyk, Y., et al.
(2005). Selective probiotic bacteria induce IL-10producing regulatory $\mathrm{T}$ cells in vitro by modulating dendritic cell function through dendritic cell-specific intercellular adhesion molecule 3 -grabbing nonintegrin. J Allergy Clin Immunol 115, 1260-1267.

Strober, W., Fuss, I.J., and Blumberg, R.S. (2002). The immunology of mucosal models of inflammation. Annu Rev Immunol 20, 495-549.

Sturm, A., Rilling, K., Baumgart, D.C., Gargas, K., Abou-Ghazale, T., Raupach, B., Eckert, J., Schumann, R.R., Enders, C., Sonnenborn, U., et al. (2005). Escherichia coli Nissle 1917 distinctively modulates Tcell cycling and expansion via toll-like receptor 2 signaling. Infect Immun 73, 1452-1465.

Sudo, N., Sawamura, S., Tanaka, K., Aiba, Y., Kubo, C., and Koga, Y. (1997). The requirement of intestinal bacterial flora for the development of an IgE production system fully susceptible to oral tolerance induction. J Immunol 159, 1739-1745.

Sutas, Y., Hurme, M., and Isolauri, E. (1996a). Downregulation of anti-CD3 antibody-induced IL-4 production by bovine caseins hydrolysed with Lactobacillus GGderived enzymes. Scand J Immunol 43, 687-689.

Sutas, Y., Soppi, E., Korhonen, H., Syvaoja, E.L., Saxelin, M., Rokka, T., and Isolauri, E. (1996b). Suppression of lymphocyte proliferation in vitro by bovine caseins hydrolyzed with Lactobacillus casei GGderived enzymes. J Allergy Clin Immunol 98, 216-224.

Takeda, K., Suzuki, T., Shimada, S.I., Shida, K., Nanno, M., and Okumura, K. (2006). Interleukin-12 is involved in the enhancement of human natural killer cell activity by Lactobacillus casei Shirota. Clin Exp Immunol 146, 109-115.

Taylor, A.L., Dunstan, J.A., and Prescott, S.L. (2007). Probiotic supplementation for the first 6 months of life fails to reduce the risk of atopic dermatitis and increases the risk of allergen sensitization in high-risk children: a randomized controlled trial. J Allergy Clin Immunol 119, 184-191.

Tien, M.T., Girardin, S.E., Regnault, B., Le Bourhis, L., Dillies, M.A., Coppee, J.Y., Bourdet-Sicard, R., Sansonetti, P.J., and Pedron, T. (2006). Antiinflammatory effect of Lactobacillus casei on Shigellainfected human intestinal epithelial cells. J Immunol 176, 1228-1237.

Vinderola, G., Matar, C., and Perdigon, G. (2005). Role of intestinal epithelial cells in immune effects mediated by gram-positive probiotic bacteria: involvement of toll-like receptors. Clin Diagn Lab Immunol 12, 1075-1084.

von der Weid, T., Bulliard, C., and Schiffrin, E.J. (2001). Induction by a lactic acid bacterium of a population of CD4(+) T cells with low proliferative capacity that produce transforming growth factor beta and interleukin-10. Clin Diagn Lab Immunol 8, 695-701.

Yan, F., and Polk, D.B. (2002). Probiotic bacterium prevents cytokine-induced apoptosis in intestinal epithelial cells. J Biol Chem 277, 50959-50965.

Zhang, L., Li, N., Caicedo, R., and Neu, J. (2005). Alive and dead Lactobacillus rhamnosus GG decrease tumor necrosis factor-alpha-induced interleukin-8 production in Caco-2 cells. J Nutr 135, 1752-1756. 


\section{Further Reading}

Caister Academic Press is a leading academic publisher of advanced texts in microbiology, molecular biology and medical research. Full details of all our publications at caister.com

- MALDI-TOF Mass Spectrometry in Microbiology Edited by: M Kostrzewa, S Schubert (2016) www.caister.com/malditof

- Aspergillus and Penicillium in the Post-genomic Era Edited by: RP Vries, IB Gelber, MR Andersen (2016) www.caister.com/aspergillus2

- The Bacteriocins: Current Knowledge and Future Prospects Edited by: RL Dorit, SM Roy, MA Riley (2016)

www.caister.com/bacteriocins

- Omics in Plant Disease Resistance Edited by: V Bhadauria (2016) www.caister.com/opd

- Acidophiles: Life in Extremely Acidic Environments Edited by: R Quatrini, DB Johnson (2016) www.caister.com/acidophiles

- Climate Change and Microbial Ecology: Current Research and Future Trend

Edited by: J Marxsen (2016)

www.caister.com/climate

- Biofilms in Bioremediation: Current Research and Emerging Technologies

Edited by: G Lear (2016)

www.caister.com/biorem

- Microalgae: Current Research and Applications Edited by: MN Tsaloglou (2016) www.caister.com/microalgae

- Gas Plasma Sterilization in Microbiology: Theory, Applications, Pitfalls and New Perspectives Edited by: H Shintani, A Sakudo (2016) www.caister.com/gasplasma

- Virus Evolution: Current Research and Future Directions Edited by: SC Weaver, M Denison, M Roossinck, et al. (2016) www.caister.com/virusevol

- Arboviruses: Molecular Biology, Evolution and Control Edited by: N Vasilakis, DJ Gubler (2016) www.caister.com/arbo

- Shigella: Molecular and Cellular Biology Edited by: WD Picking, WL Picking (2016) www.caister.com/shigella

-Aquatic Biofilms: Ecology, Water Quality and Wastewater Treatment

Edited by: AM Romaní, H Guasch, MD Balaguer (2016)

www.caister.com/aquaticbiofilms

- Alphaviruses: Current Biology

Edited by: S Mahalingam, L Herrero, B Herring (2016)

www.caister.com/alpha

- Thermophilic Microorganisms

Edited by: F Li (2015)

www.caister.com/thermophile
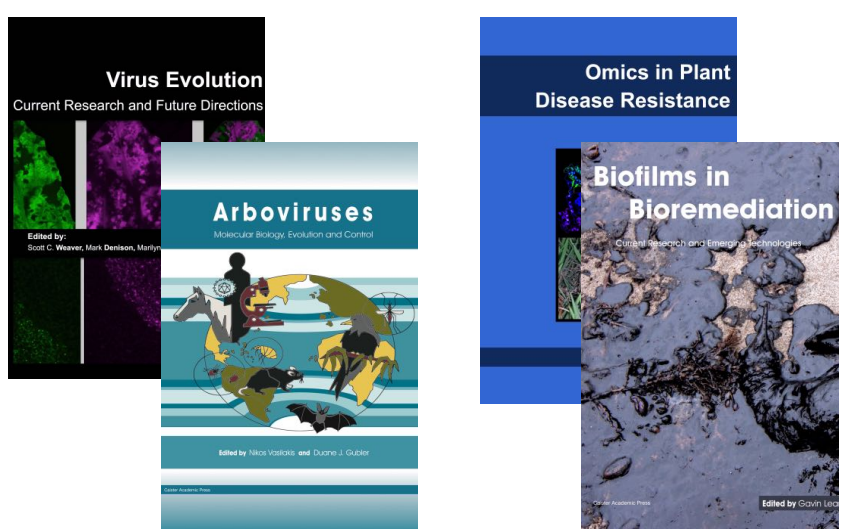
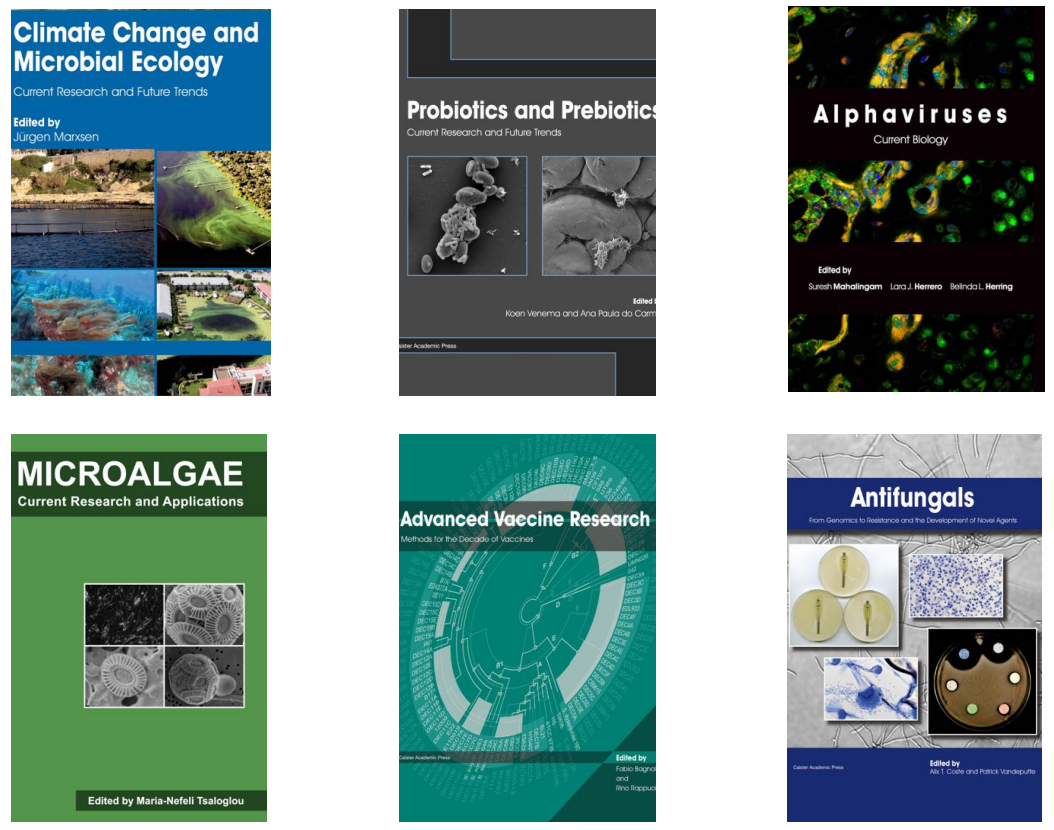

- Flow Cytometry in Microbiology: Technology and Applications Edited by: MG Wilkinson (2015) www.caister.com/flow

- Probiotics and Prebiotics: Current Research and Future Trends Edited by: K Venema, AP Carmo (2015) www.caister.com/probiotics

- Epigenetics: Current Research and Emerging Trends Edited by: BP Chadwick (2015) www.caister.com/epigenetics2015

- Corynebacterium glutamicum: From Systems Biology to Biotechnological Applications

Edited by: A Burkovski (2015)

www.caister.com/cory2

- Advanced Vaccine Research Methods for the Decade of Vaccines

Edited by: F Bagnoli, R Rappuoli (2015)

www.caister.com/vaccines

- Antifungals: From Genomics to Resistance and the Development of Novel Agents

Edited by: AT Coste, P Vandeputte (2015)

www.caister.com/antifungals

- Bacteria-Plant Interactions: Advanced Research and Future Trends Edited by: J Murillo, BA Vinatzer, RW Jackson, et al. (2015) www.caister.com/bacteria-plant

\section{- Aeromonas}

Edited by: J Graf (2015)

www.caister.com/aeromonas

- Antibiotics: Current Innovations and Future Trends

Edited by: S Sánchez, AL Demain (2015)

www.caister.com/antibiotics

- Leishmania: Current Biology and Contro Edited by: S Adak, R Datta (2015) www.caister.com/leish2

- Acanthamoeba: Biology and Pathogenesis (2nd edition) Author: NA Khan (2015)

www.caister.com/acanthamoeba2

- Microarrays: Current Technology, Innovations and Applications Edited by: Z He (2014)

www.caister.com/microarrays2

- Metagenomics of the Microbial Nitrogen Cycle: Theory, Methods and Applications

Edited by: D Marco (2014)

www.caister.com/n2 